\title{
COMPETITION FOR UNIVERSITY PLACES AND PARENTAL TIME INVESTMENTS: EVIDENCE FROM THE UK
}

\section{Cristina Borra and Almudena Sevilla}

Across the industrialized world college-educated parents invest more time in their children relative to non-college educated parents. Yet, the reason for the education gradient in parental time investments is not well understood. Using 24-hour diary surveys since the 1970s we document an inverse U-shape in the education gradient in the UK. Theories unfolding gradually and monotonically cannot easily explain this pattern. Using an exogenous increase in the number of students going onto university in the 1980s, we show that an alternative explanation based on competition for university places can explain the temporal and spatial variation in the education gradient. (J13, J24.)

Keywords: time investments, parental education, university admissions.

Cristina Borra: Department of Economics and Economic History, Universidad de Sevilla, Ramon y Cajal 1, Seville 4018, Spain (e-mail: cborra@ us.es);

Almudena Sevilla (corresponding author): School of Business and Management, Queen Mary, University of London, Francis Bancroft Building, Mile End Road, London E1 4NS. (email: a.sevilla@qmul.ac.uk).

This work was funded by the ESRC under grant ES/K003127/1. 


\section{INTRODUCTION}

Parental time investments play an important role in the intergenerational transmission of human capital and are an important contributor to children's developmental outcomes (e.g., Fiorini and Keane 2014; Heckman and Mosso 2014; Ichino et al. 2011). Yet, across the industrialized world there is an increasing divergence in the time that college-educated parents spend with their children relative to non-college educated parents (Gimenez-Nadal and Sevilla, 2012). Given that a large proportion of the variability of lifetime earnings results from traits determined early on in a child's life (Cunha and Heckman, 2007), understanding the causes behind the growing inequality in the time parents spend with their children is of critical importance for research on child development and for policies aimed at reducing inequality. In this paper we ask the following question: Can competition for college slots at elite universities explain the trends in the education gradient in parental time investments in the UK?

Using five UK 24-hour diary surveys covering 1974-2005 we first document a non-monotonic increase in the education gradient in parental time investments over this period. Whereas in the 1970s college educated mothers devoted about 40 minutes per week more than non-college educated parents, by the mid 1990s college educated parents had increased the time they spent with their children by twice as much as parents with non-college education (with gaps reaching three and a half hours per week for mothers and almost one hour per week for fathers). By the end of the period parental time investments for parents with different educational attainment converged, although college-educated parents and their children spent substantially more time doing human capital enhancing activities (such as reading, and doing homework) than non-college educated parents.

We explore an explanation based on the competition for university slots at selective institutions building on the theoretical framework of Ramey and Ramey (2010). In particular, we test the hypothesis that higher educated parents may be caught up in a rug rat race in which parents adjust their time investments as competition for elite college slots changes. When slots at selective institutions are 
abundant all children from higher educated backgrounds go to first-tier universities and the remaining slots are filled with children from lower educated backgrounds. An exogenous shock driving competition for first-tier university slots upward intensifies the rivalry among higher educated parents. This increased rivalry drives up parental time investments of college-educated parents relative to less educated parents, more so in parental activities contributing to children's skills more highly valued by university admission boards. The opposite happens as competition for first-tier university slots goes down.

We empirically test the college competition hypothesis by exploiting policy changes in the UK's educational system, which created a U-shape in the competition for college slots at elite institutions. We use the exogenous variation in the number of students going onto university driven by two distinct policy shocks. The first policy shock is the introduction of the General Certificate of Secondary Education (GCSE) in 1988 (Education Reform Act-1988), which led to a 40 per cent increase in the proportion of students staying on beyond the compulsory school leaving age resulting in an increase in the competition for college slots (see Figure 1 in Blanden and Machin, 2004). The second policy shock is the enactment of the 1998 Teaching and Higher Education Act, introducing up-front means-tested tuition fees in 1998 leading to a much weaker demand for demand for university places after the mid 1990s and a decline in competition for college slots (Greenaway and Hayness 2002, Clark 2011, Dearden et al 2011). This change to entry rates to college was exogenous from the perspective of parents. In both cases, parents could not have possibly anticipated the changes in college competition resulting from these policy shocks, because the policy shocks were themselves unexpected.

Our empirical design uses these policy shocks to explain the temporal and spatial variation in the education gradient in parental time investments in the UK, and exploits the nature of the university admissions in the UK to rationalize the types of activities that college-educated parents and their children engage in. To that end, we put together administrative data on university admissions from 
different sources from the mid 1970s, and construct a historical series of college competition based on the proportion of students securing a slot at elite institutions and relative entry qualifications at elite versus non-elite universities.

We show that the inversed U-shaped pattern in the education gradient in parental time investments matched the U-shaped pattern in college competition, particularly in regions were competition was fiercer. We demonstrate that the increase in the education gradient in parental time investments during the mid 1970s until the mid 1990s coincided with an increase in college competition at elite universities. During this period there was a 13 percent decrease in the proportion of students attending elite universities (from 46 to 40 percent), and the relative entry qualifications at these institutions increased by about 40 percent (from 12 to 17 percent higher). Similarly, the decline in the education gradient in parental time investments that occurred from the mid 1990s onwards coincided with a drop in the competition for college slots at selective universities. Spatial variation in the different competitive pressures across UK regions also reveals that the increasing divergence in parental time investments between college and non-college educated parents until the mid 1990s, and the convergence thereafter, were mainly driven by parents in regions with high college competition levels. We also provide evidence showing that traditional theories that unfold gradually and monotonically cannot explain the inverse U-shaped pattern in the education gradient in parental time investments.

Our findings add to three strands of the economics literature. First, we contribute to the education gradient literature in parental time investments, which has mostly focused in the US, by exploring the factors that are important in explaining parental time investments for parents with different educational backgrounds (see Leibowitz 1975; Guryan et al. 2008; Ramey and Ramey 2010). Second, by offering an explanation to the diverging patterns in time investments for children and parents from different educational backgrounds across regions and over time in the UK, we complement the inequality literature by identifying one possible channel through which the intergenerational transmission of human capital takes place (see Black and Devereux 2011; Fiorini and Keane 2014; Richey and Rosburg 
2017). Third, we add to the literature on inequality in university access by showing for the first time unique evidence on increased competition for slots at elite universities in the UK after the introduction of changes in the educational system (Bhattacharya et al. 2016; Bound et al. 2009; Dillon and Smith 2017; Hoxby 2009; Jerrim et al. 2015).

The paper is organized as follows. Section 2 documents trends in parental time investments in the UK over the last decades, paying particular attention to the education gradient. Section 3 explains the institutional background and policy shocks that led to exogenous changes in competition for college slots. Section 4 presents several pieces of evidence that all point in the direction of college competitive pressures at elite schools as one of the drivers for the U-shaped patterns in the education gradient in parental time investments in the UK. Section 5 rules out traditional theories brought forward in the literature as explanations for how the gap in parental time investments between parents with a college degree and non-college educated parents has evolved in the UK. Section 6 concludes.

\section{TRENDS IN THE EDUCATION GRADIENT ON PARENTAL TIME INVESTMENTS}

We use 24-hour time diary surveys from the 1974, 1983, 1995, 2000, 2005 UK Multinational Time Use Study Data set (UK MTUS) to provide a comprehensive picture of historical trends in parental time investments and children's time use ${ }^{1}$. Time use diaries have become the preferred method to collect information on time spent on different activities just as money expenditure diaries have become the gold standard for describing consumption behaviour, and most studies documenting long term trends in how individuals use their time are based on time-use diaries (Aguiar and Hurst 2007, Gimenez-Nadal and Sevilla 2012). The Multinational Time Use Study (MTUS) is an ex-post harmonized cross-time cross-national comparative time-use database that aggregates daily activities in 40 time use categories with approximately 30 standardized demographic variables (see Fisher and

\footnotetext{
${ }^{1}$ See Table A1 in Appendix A and Appendix B for a description of these surveys.
} 
Gershuny (2013) for a description of the time-use surveys in the MTUS). Both the 1995 and the 2005 diaries were administered alongside OMNIBUS Studies. These "light diary" surveys are time budget instruments suitable for use as add-on components to other surveys without unduly increasing respondents' burden, as respondents can only choose among 30 pre-coded activities (Gershuny and Smith 1995). Compared to the 1995 and 2005 light diaries, the responses about the use of time in the 1974, 1983, and 2000 "standard diary" surveys were freely indicated by respondents and then coded by the research teams into over 60 activities. The purpose of this paper is the comparison of parental time between educational groups, which should only reflect changes in actual behaviour rather than changes in survey methodology as there is no reason to believe that college and non-college educated parents are affected by data collection methods in different ways (Aguiar and Hurst 2007, Ramey and Ramey, 2010).

For comparability with previous studies (see Ramey and Ramey, 2010) we use four measures of parental time investments: total time investments and general care, teaching care, and playing care. The classification of total time investments into finer categories is only possible in the 1983 and 2000 surveys, which provided a considerably larger classification of parental activities with children. ${ }^{2} \mathrm{We}$ also consider three categories of children's time use: travel time, time spent in school and after-school classes, and time spent in homework and study. ${ }^{3}$ As the 1995 and 2005 surveys are not household surveys and do not offer information on maternal education for the children who fill out the diaries, the analysis of children's time also only employs the 1974, 1983, and 2000 surveys.

The analysis of parental time includes mothers and fathers aged 18 to 64 who are neither retired nor students. We restrict the sample to households where the youngest child is older than 5 years old to ensure that time devoted to childcare on the part of parents is actually invested in older children. ${ }^{4}$ The

\footnotetext{
2 Table A.2 in Appendix A describes how these variables are constructed from the original activity codes.

3 These categories are constructed from the original activity codes as shown in Table A.3 in Appendix A.

${ }^{4}$ In all household-level and individual-level diary surveys we have information on whether the younger child in the household is older than 5.
} 
final sample includes 5,935 mothers and 4,568 fathers. In the analysis of children's time we restrict the sample to children aged 14 and over because younger children did not fill out the diary in the 1983 survey. The final sample includes 3,333 children.

Table 1 provides the descriptive statistics for the main dependent variable, the hours per week spent on childcare, by year and parental educational level. The descriptive evidence in Table 1 clearly indicates a much higher parental time investments (about 3 hours per week more for mothers and 2 hours more for fathers) from light diary surveys (1995, 2005) than from standard diary surveys (1974, 1983, and 2000), suggesting that respondents report higher levels of parental time investments when filling out a light diary rather than a standard diary (Gatenby 2003). Comparisons of parental time investment in the 1995 and 2005 light diaries with the 1974, 1983, and 2000 standard diaries may thus capture different survey methodologies rather than behaviour.

To the extent that survey methodology does not differently affect the reports of parental time investments for parents with different educational attainment, comparisons of the education gradient in parental time investments across time should capture genuine behavioural changes on the part of college and non-college educated parents, rather than a result from survey methodological differences. Results from Table 1 suggest this to be the case. If college-educated parents reported higher levels of parental time investments when filling out a light diary (relative to a standard diary) than non-college educated parents, we should expect to observe this over-reporting of parental time investments by college-educated parents in both the 1995 and the 2005 light diary surveys. Yet, we clearly see that whereas college-educated parents reported about 3 more hours per week in parental time investments than non-college educated parents in 1995 , the difference between educational groups was close to 0 in 2005.

$\underline{\text { Trends in the Education Gradient in Parental Time Investments }}$ 
Parental time investments over time are estimated using the model in Equation (1) as:

$$
C T_{i t}=\beta_{1} H_{i t}+H_{i t} \mathbf{T}_{\mathbf{t}} \mathbf{\beta}_{2}+\mathbf{X}_{\mathbf{i t}} \boldsymbol{\beta}_{3}+\delta_{t}+\varepsilon_{i t}
$$

Where $C T_{i t}$ is total time in hours per week in parental time investments by respondent $(i)$ in year $(t)$. $H_{i t}$ is a dummy variable that takes value one if educational attainment is some college or more, and $\mathbf{T}_{\mathbf{t}}$ is a vector of survey-year dummies. $\mathbf{X}_{\mathbf{i t}}$ is a set of controls to hold constant the demographic composition of the sample. In particular we include a vector of dummies controlling for the age group of the individual (ages 18-24, 25-34, 35-44, 45-54, and 55-64), marital status, the number of children, the number of children squared, and a vector of dummies to control for the day of the week the diary was reported (reference Sunday). ${ }^{5}$ We also include survey-period fixed effects $\left(\delta_{t}\right)$ to account for longterm changes in attitudes towards children from both college-educated and less-than-college educated individuals. $\varepsilon_{i t}$ is the error term clustered at the survey level. In all the analyses, MTUS proposed weights are used to ensure population, day of the week, and seasonal representativeness, and assign zero weights to low quality diaries, i.e. diaries having more than 90 minutes of missing time, fewer than 7 episodes, missing two or more of four basic activities, or being filled by a diarist of unknown age or sex. Our coefficients of interest are the coefficients for the college education indicator $\left(\beta_{1}\right)$ and all the interaction terms between the college education indicator and the survey-year dummies $\left(\beta_{2}\right){ }^{6}$

Results from estimating Equation (1) for mothers' weekly total time investments are presented in Column 1 of Table 2. Trends in parental time investments confirm the descriptive evidence in Table 1. Focusing on the year dummies for the 1974, 1983 and 2000 surveys, which use similar methodologies, we find that the average amount of time spent by non-college educated mothers (our baseline category) increased about 3 hours per week from 1974 to 2000 (Column 1 of Table 1). The increase in time

\footnotetext{
5 Descriptive statistics of controls are provided in Table A.5 in Appendix A. Results hold when only controlling for age, as in Ramey and Ramey's (2010) benchmark specification.

6 As Ramey and Ramey (2010) we consider just the college educated versus other educational categories. Harmonization issues when using data spanning over more than three decades prevent us from using a more detailed categorization of educational attainment.
} 
investments over time has previously been documented for the US and other developed countries (Aguiar and Hurst 2007, Ramey and Ramey 2010, Gimenez-Nadal and Sevilla, 2012). For instance, Ramey and Ramey (2010), using a similar methodology, report average increases in maternal childcare time of about 4 hours in the United States from 1975 to 2008. Evidence from Gimenez-Nadal and Sevilla (2012) on trends in time allocation shows comparable increases in parental time investments of about 2 hours for seven industrialized countries including the UK from the 1970s to the 2000s. Explanations offered by the literature for this overall increase in parental time investments include selection into parenthood (Bianchi et al. 2006) and changing parenting styles (Doepke and Zilibotti 2017).

Consistent with the evidence from developed countries that more educated parents invest more time in childcare activities, results for the dummy on maternal education in Column 1 of Table 2 show that over this period college-educated mothers invested on average one hour more per week on children than non-college educated mothers. For instance Guryan, Hurst and Kearney (2008) report that collegeeducated women spent more than 6 hours per week in childcare than their high-school dropout counterparts in the United States in 2003-2006 at the end of our study period. Gimenez-Nadal and Sevilla (2012) report average differences of about 2 hours (ranging from one to 6 hours) between college educated women and their high-school dropout counterparts during the 1990s.

Results for the coefficients for the college education indicator and its interactions with the surveyyear dummies in Column 1 of Table 2 show that trends in the education gradient in time investments reveal a divergence in time investments by parental education until the mid 1990s, fading away towards the end of the period. Whereas in the 1970 s college educated mothers devoted 40 minutes more per week than non-college educated mothers to childcare, the gap in maternal time investments had relatively increased to more than an hour per week in 1983 and, by 1995, college educated mothers invested 3.5 more hours per week than their non-college educated counterparts. After that, however, 
college educated mothers devoted just half an hour more to childcare than non-college educated mothers in 2000, and by 2005 both educational groups devoted approximately the same amount of time. This is in stark contrast to the monotonically rising education gradient in parental time investments reported by Ramey and Ramey (2010) for the United States, where the differences in time investments between college and non-college educated mothers rose from virtually zero in 1975 to 4 hours in 2000 and 6 hours in 2005.

Results from estimating Equation 1 for the sample of fathers in column 5 of Table 2 show that the education gradient in time investments for fathers followed a similar pattern to the pattern found for mothers, reaching about one hour per week in 1995, and gradually decreasing afterwards. Figure 1 shows that whereas the inverse U-shape in the education gradient in maternal time investments were mirrored with simultaneous U-shaped patterns in the education gradient in unpaid work and leisure time, the inverse U-shaped patterns in the education gradient in fathers time with children were mirrored by symmetric changes in the education gradient in paid work and housework.

Available information on the type of activity available from the 1983 and 2000 surveys suggests that, although at the end of the period mothers spent roughly the same amount of time with their children independent of their educational levels, this convergence did not occur for time spent in educational activities. In particular Column 3 of Table 2 show that whereas in 1983 college educated mothers devoted 10 minutes more to educational childcare (e.g. teaching children, helping them with homework), by 2000 college-educated mothers invested half an hour more in educational childcare than non-college educated mothers. We also find increases in the differential time devoted by collegeeducated fathers over their non-college counterparts to educational activities during this period, although the magnitudes are lower (Column 7 of Table 2).

Consistent with the evidence presented for parental time investments in educational activities presented in Columns 3 and 7 of Table 2, columns 1 to 3 in Table 3 show that in the UK children from college educated backgrounds increasingly spend more time in human capital enhancing activities, 
such as time devoted to homework and study. The coefficients for the college educated dummy and its interactions with the year dummies in Column 1 show that whereas in the 70 s children devoted the same amount of time to homework regardless of their parents' educational background, from the mid 1980s onwards children from more educated family backgrounds spent four hours per week doing homework, almost twice as much time as children from non-college educated backgrounds. Compared to children from non-college educated backgrounds, children from college-educated backgrounds show a positive gap in school and other classes throughout the period. However the gap decreased about two hours from the mid 1970s to the mid 1980s.

Overall our results show an inverse U-shaped pattern in the education gradient in parental time investments over this period. We cannot evaluate the hump shape for specific types of parental and children's time investments because there is only one time use survey at the time of the hump (the UK 1995 time diary survey), and it did not contain information on the type of activities that parents did, nor information on parental education of children who filled the diary. Available information on types of parental activities with children in the 1983 and 2000 surveys, along with children's time use from the 1974, 1983, and 2000 surveys, shows an increase in educational-related activities by parents and children, particularly for the more educated.

\section{INSTITUTIONAL BACKGROUND: SHOCKS TO COLLEGE COMPETITION AT ELITE UNIVERSITIES IN THE UK}

To identify the association of college competition in and the education gradient in parental time investments we use exogenous variation in the demand for college slots at elite institutions driven by two distinct policy shocks: the introduction of the General Certificate of Secondary Education (GCSE) in the 1988 Education Reform Act, and the introduction of up-front means-tested tuition fees in the 1998 Teaching and Higher Education Act. The competition for college followed these changes in the 
demand for college slots, increasing from the mid 1970s to the mid 1990s and decreasing afterwards, given that the supply of university places remained relatively constant over the whole period. ${ }^{7}$

The UK Higher Education admissions' system is a national, centralized process managed by the Universities Central Council on Admissions (UCAS). Teenage children apply to up to six subjectinstitution combinations ranked by preference. Universities make their admission decisions, mainly based on prior grades. Most UK applicants sit A-levels on three subjects at age 18 at the end of the two-year post compulsory education. There are different examination boards, but the evaluation system is centrally coordinated and therefore average A-level scores are considered to be directly comparable across institutions (see Bhattacharya et al., 2016, among others). Admissions are rarely based on subjective assessments of student motivation or performance at interview (Jerrim et al., 2015), and the majority of higher education institutions use grades in A-level qualifications as the main criteria for university entry, the other options being the Scottish Certificate of Higher Education and foreign qualifications (Walker and Zhu, 2017).

The UK has a well-defined core of elite universities such as Oxbridge, Redbrick Universities, and the Russell Group (Sutton Trust and the Department for Business Innovation, and Skills, 2009). Students choose which institution to enrol from those admitting them (Bratti 2002, Abbott and Leslie, 2004). The great majority of UK students study full-time, degrees taking about three years to complete. Existing evidence shows that distance is the strongest factor influencing university choice amongst those attending university, with over fifty per cent of students studying in their local region (Gibbons and Vignoles, 2012). This figure is very similar to the percentage of "in-state" students in US private colleges (Hoxby, 1997). For example, a ten percent increase in home-to-university distance decreases the probability of attending that specific university also by 10 percent (Gibbons and Vignoles, 2012).

\footnotetext{
7 In 1993 the British Government introduced a cap on the maximum number of students for which the university obtained funding, the Maximum Aggregate Student Numbers (MaSN). MaSN targets were however persistently larger than actual recruitment. In 2000-01, just before the abolition of this cap in England, some 14,465 funded places remained unfilled (HEFCE, 2001; Abbott and Leslie, 2004).
} 
From the late 1980s till the mid 1990s the introduction of GCSEs in 1988 led to an exogenously driven increase in competition for college slots. GCSEs are national examinations taken when students reach the age of 16 in specific subjects. The reform was introduced to end the previous two-tier system separating children into high and low education streams, in which students could either take Ordinary (O)-levels, if they aimed to stay beyond compulsory education, or the Certificate of Secondary Education, if students did not want to pursue further education. Following the introduction of GCSE there was a step-change of 40 per cent increase in the proportion of students staying on beyond the compulsory school leaving age from 51 per cent in the late 1980s to 70 per cent in the early 1990 s (see Figure 1 in Blanden and Machin, 2004).

After the mid 1990s the 1998 Teaching and Higher Education Act led to an exogenously driven decrease in competition for college slots. Despite increases in the college education age population (HEFCE, 2001) and a relatively stable proportion of secondary students staying on beyond compulsory education (Blanden and Machin 2004), the introduction of means-tested tuition fees together with the replacement of maintenance grants with student loans in 1998 led to a much weaker demand for demand for university places after the mid 1990s (Greenaway and Hayness 2002, Clark 2011, Dearden et al 2011).

Our identification strategy relies on two assumptions. First, that the policy changes are not a reaction to parents' behaviour, and therefore endogenous. We exploit the timing of the diary surveys and the policy shocks to rule out the endogeneity of the policies. The introduction of GCSEs took place in 1988, between the 1983 and 1995 surveys; the introduction of tuition fees took place in 1998, between the 1995 and 2000 surveys. Parents could not have possibly anticipated the changes in college competition resulting from these policy shocks, because the policy shocks were themselves unexpected. The notion of a national curriculum envisaged in the GCSCs was first presented in a government consultation document in 1987 (Gilliard 2011, Department of Education and Science 1987). Therefore 
parents in our 1983 survey could have not anticipated this policy change. Similarly, the need for radical funding changes that ultimately led to the 1998 Teaching and Higher Education Act were first recognized in the Dearing report (1997). Thus parents in the 1995 time diary survey could have not been aware of the changes to tuition fees and university grants proposed by the 1998 Education Act.

The second identification challenge is related to the fact that the observed correlation between college competition and parental time investments may not be due to another unobserved underlying variable correlated with both college competition and parental time investments. In Section V we address this identification challenge by ruling out alternative explanations to the documented changes in parental time investments over this period.

\section{COLLEGE COMPETITION AND PARENTAL TIME INVESTMENTS IN THE UK}

In this section we test the theoretical framework of Ramey and Ramey (2010) by exploiting the time variation and cross-regional variation in college-competition levels in the UK. To that end we construct measures of college competition over this period by putting together a novel enrolment and average qualification time series from several administrative data sources since the 1970s. Student enrolment numbers until the mid 1990s come from the Universities' Statistical Record (USR), which collected annual individual student records for the full population of undergraduate students at university from 1974/75 to 1993/94. Enrolment numbers at the university level for later years come from the Higher Education Statistics Agency (HESA). Advanced (A)-level entry qualifications by institution from 1974/75 to 1993/94 are calculated using student-level information on A-level qualifications from USR, and we use information on A-level entry qualifications at the university level from the Times Higher Education Supplement (THES) between 1996/97 and 1999/2000 .

\footnotetext{
8 Data from Abbott and Leslie (2004), provided by the authors. HESA data on students' A-levels was only available from 2007 onwards, as indicated in e-mail communication. More detailed information on data gathering offered in Appendix B.
} 
In order to keep the number of universities constant throughout the period we limit the sample to existing universities before the passage of the 1992 Further and Higher Education, which granted university status to 48 former polytechnics (see Greenaway and Haynes, 2003). ${ }^{9}$ We consider elite universities those universities belonging to the Russell Group founders. ${ }^{10}$ The Russell Group is an association of research-intensive UK universities created in 1994 generally regarded to be amongst the most prestigious universities in the UK and recognized as a selective group (Walker and Zhu 2017). ${ }^{11}$

Our first measure of competition for elite university places is the probability of attending an elite institution (see Table 4). This probability is constructed as the ratio of the annual number of full-time undergraduate students attending elite institutions divided by the number of full-time undergraduate students attending elite and non-elite universities in the UK. Students can only apply to a fixed number of universities. As a result, elite universities receive fewer applications than non-elite institutions because only students who are sure to meet their strict entry standards apply to them (Abbott and Leslie, 2004). By focusing on actual slots rather than acceptances we take into account the strategic behavior on the part of students (Bound et al., 2009).

In the spirit of Hoxby (2009), our second measure of competition for slots at elite universities is the relative entry qualifications of students admitted to elite universities compared to all universities (see Table 4). To that end we construct the ratio between the average A-levels entry score at elite institutions and the average A-levels entry score at elite and non-elite institutions, weighted by the proportion of UK students attending each institution. The rationale behind this measure is that increases in competition should be accompanied by increases in the selectivity of elite institutions, which should be reflected in higher average entry qualifications relative to non-elite universities (Hoxby, 2009). By

\footnotetext{
${ }^{9}$ Trends in enrollment rates are similar when including post-1992 universities in the analysis (as shown in Column 1 in Table A.5 in Appendix A).

10 Russell Group founders are Birmingham, Bristol, Cambridge, Edinburgh, Glasgow, Imperial College London, Leeds, Liverpool, London School of Economics, Manchester, Newcastle, Nottingham, Oxford, Sheffield, Southampton, University College London, and Warwick. Results are qualitatively the same when including non-founding Russell Group members: Cardiff University, King's College London (in 1998), Queen's University Belfast (in 2006) Durham, Exeter, Queen Mary University of London, and York (in 2012).

${ }^{11}$ In Tables A.5 and A.6 in Appendix A we show that the trends in college competition are similar across alternative definitions of elite institutions considered in the literature (Moodie 2006), including Oxbridge, ancient universities in Scotland, and civic universities (see Appendix B).
} 
comparing relative scores between elite and the rest of institutions we also overcome recent criticisms on the declining standards in A-levels examinations and increasing scores over time (Coe and Tymms, 2008).

\section{Exploiting the Temporal Variation in College Competition}

We show that by the end of the period considered here (mid 2000s) the competition for college slots was still higher than what it was in the 1970s. Yet whereas up to the mid 1990s competition for college slots at elite universities increased substantially, the competition for college decreased thereafter.

Panel A in Figure 2 plots the proportion of students attending elite institutions from Column 3 in Table 4. It shows that over the entire period, the proportion of students attending elite universities dropped by 8 per cent, from about 46 per cent to 42 percent. In particular, whereas the proportion of students attending elite universities decreased by 13 per cent (from 46 to 40 percent) from the mid 1970s until the mid 1990s, the proportion of students in elite universities actually increased about 5 per cent to 42 percent from the mid 1990s to 2005.

Panel B in Figure 2 plots relative scores from Column 6 in Table 4. Compared to non-elite universities, relative entry examination results at elite universities increased approximately by 16 percent. Similar to relative enrolment rates, relative entry scores increased by about 40 per cent between the mid 1970s until the mid 1990s and dropped thereafter. Entry scores were 12 per cent higher in elite universities than in non-elite universities in 1974 and the difference in entry scores between elite and non-elite universities continued to increase up until the mid 1990s reaching a peak in 1995, when entry scores in elite universities were 17 per cent higher than in non-elite universities. From the mid 1990s to the early 2000s the gap in entry scores between elite and non-elite universities fell by about three percentage points, from 17 to 14 per cent. Notwithstanding, relative scores were still higher than in the mid 1970s.

Panel $\mathrm{C}$ in Figure 2 plots the trends in the education gradient in parental time documented in Table 2, and shows a striking correspondence with competition for university places at elite institutions depicted 
in Panels A and B. In particular, from the mid 1970s to the mid 1990s the gaps in parental time investments by parental educational attainment increased (Panel C) coinciding with a decrease in the relative number of students attending elite institutions (Panel A), and an increase in entry qualifications of students attending elite universities relative to students attending non-elite universities (Panel B). Subsequently, from the mid 1990s onwards, while parental time investments by educational attainment converged (Panel C), the competition for college slots at selective universities decreased, as the proportion of students at elite institutions increased (Panel A), and average entry qualifications of the students attending these universities decreased (Panel B).

We also observe that toward the end of the period college competition was higher than in the mid 1980s, consistent with the gap in educational activities of college-educated parents and their children in relation to non-college educated parents over the entire period in Tables 2 and $3 .^{12}$

\section{Exploiting the Spatial Variation in College-Competition}

In this section we test the hypothesis that student applicants' behaviour is more sensitive to changes in competition for college in their region, particularly in the context of mobility constraints (Gibbons and Vignoles 2012). To study changes in competitive pressures across regions over time we compute the proportion of students in elite universities over total students, and the ratio of average entry scores at elite institutions relative to non-elite institutions by region ${ }^{13}$ using the seven regions in the MTUS: North of England, England Midlands, East of England, London and South East England, South West England, Wales, and Scotland. ${ }^{14}$

\footnotetext{
12 Notice that overall increases in college competition from the mid 1980s to the early 2000s would also be consistent with the overall increases in parental time investments documented in Tables 1 and 2. As explained in Section I methodological differences between the 1995 and 2005 "light diary" surveys and the 1974, 1983, and 2000 "standard diary" surveys prevents us from assessing any hump in the levels of parental time investments in the mid 90s.

${ }^{13}$ See Tables A.7 and A.8 in Appendix A.

${ }^{14}$ None of the Welsh Higher Education institutions belonged to the Russell Group in the mid 1990s, so the proportion of students at elite universities in Wales is constant and equal to zero, and the relative score is also constant and equal to one. None of the Welsh Higher Education institutions belonged to the Russell Group in the mid 1990s, so the proportion of students at elite universities in Wales is constant and equal to zero, and the relative score is also constant and equal to one. Ethnic minority groups have been found to be especially sensitive to distance in their choice of higher education institution (Gibbons and Vignoles 2012). We lack, however, ethnic background data before 1995 to conduct the analysis across regions and ethnic groups.
} 
Figure 3 plots trends in relative enrolment rates and average scores at elite universities by region. It is clear that a few highly competitive regions mainly drive the trends in competition for college slots documented before. Panel A plots enrolment rates by region and shows that while the proportion of students at elite universities remained basically constant in North of England, England Midlands, South West England, and Wales (not shown in graph), it decreased dramatically till the mid 1990s in London and South East England, as well as in the East of England. The number of students enrolled at elite universities relative to the number of students enrolled in elite and non-elite universities in Scotland also decreased during this period. After the mid 1990s, the proportion enrolled at elite universities increased in London and South East England, by far the largest region in number of students and universities. Relative scores at elite universities followed a similar trend to student numbers by region. Panel B plots relative scores by region and similarly shows that while relative scores in North of England, English Midlands, and Wales (not shown) remained relatively constant, relative scores in London and South East, East of England, and, to a lower extent, Scotland followed a clear hump shape, increasing till the mid 1990s to decrease thereafter.

Due to small sample sizes it is not possible to compare trends in education gradients in parental time investments to trends in college competition within each of our seven regions. Instead, based on the analysis in Figure 3, we group UK regions into high- and low-competition regions and test the robustness of our results to different classifications of UK regions into high- and low- competition regions. We consider two alternative definitions of high-competition regions for completeness. Our first definition considers London and South East England and East of England, which show the largest increase in competition and coincide with the regions where Oxford and Cambridge are located (Oxbridge regions). Our second definition includes Scotland among the high-competition regions, which also shows a moderate increase in competition up to mid 1990s and a decrease in competition thereafter. This definition coincides with regions where the ancient universities of the Robbin's Report (1963) are located (Ancient regions). 
Columns 1 to 4 of the coefficients for the interactions of the college educated dummy with the year dummies in Table 5 show that our results in Table 2 are mainly driven by the differentiated behavior of college-educated and non-college educated mothers in high competition regions. In particular, education gradients in time investments by mothers in London, South East and East of England (Oxbridge regions) increased about eight hours per week from the mid 1980s to the mid 1990s, whereas education gradients in time investments of mothers in the other regions (Non-oxbridge regions) decreased about half an hour over that period. A similar result is found for fathers' education gradients in time investments, as shown by the coefficients of the interaction of the college dummy with the year dummies in Columns 5 to 8 in Table 5. The results in Table 2 are driven by the differentiated behavior of college and non-college fathers in high-competition regions, either where Oxbridge universities are located (Column 5) o where ancient universities are located (Column 7). ${ }^{15}$ Results in Table 5 are robust to including a wider set of socio-economic characteristics including family income, suggesting that the regional trends in the education gradient are not driven by regional wage differentials and inequality (Blackaby and Manning 1990). ${ }^{16}$

\section{ALTERNATIVE EXPLANATIONS}

In this section we conduct different robustness checks to show that conventional explanations commonly brought forward by the literature to explain the education gradient in parental time investments are based on gradual and monotonic changes, which make them hard to pair up with the inverse U-shaped patterns displayed by the education gradient in parental time investments documented in Section 2.

$\underline{\text { Selection effects }}$

\footnotetext{
15 Sample sizes of high and low competition regions for the 1995 and 2005 surveys are low. Results in Table A.9 in Appendix A show that our results are qualitatively the same when using the 1974, 1983, and 2000 surveys.

${ }^{16}$ See Table A.10 in Appendix A.
} 
The selection effects hypothesis argues that individuals who decide to become parents, especially college-educated individuals, may have a greater motivation to invest heavily in children (see Ramey and Ramey, 2010). Thus increases in selection into parenthood and a subsequent decrease over this period could in principle explain the inverse U-shaped patterns in the education gradient in parental time observed over this period. We include non-parents to account for selection effects as in Ramey and Ramey (2010). Columns 1 and 2 in Table 6 show that the trends in parental time investments depicted in Columns 1 and 5 in Table 2 hold for this sample, suggesting that selection effects are not behind the U-shape patterns in parental time investments.

\section{Compositional effects}

Increases in parental time investments up to the mid 1990s could be explained by the fact that parents going to college education in the 1990s valued education more than the minority with college education in the 1970s. In fact, at the beginning of the period just 10 per cent of our sample had at least some college, whereas in the mid 1990s 21 per cent did. Following Aguiar and Hurst (2007), Columns 3 and 4 in Table 6 show that results in Columns 1 and 5 in Table 2 are robust to using an alternative measure of highly educated $H_{i t}$ that defines as highly educated the top 30 per cent in all the surveys.

\section{$\underline{\text { Money-budget Constraints }}$}

To the extent that children are luxury goods whose consumption increases with income (Guryan et al., 2008), a widening of the income gap up to the mid 1990s and subsequent decline would be consistent for the inverse U-shape in the education gradient in time investments over this period. Indeed, existing evidence documents a sharp rise in the college wage premium from 48 to 60 percent during the 1990s, which slows down to 64 percent by 2004 (Machin and van Reenen 2008). Columns 5 and 6 in Table 6 include income as an additional control in our main specification in Equation (1). Trends in the education gradient remain virtually unchanged with respect to the results in Columns 1 and 5 Table 2.

$\underline{\text { Time-budget Constraints }}$ 
Being unemployed or having more flexible work frees time to spend in childcare could also explain the increasing gap in parental time investments between college and non-college educated mothers to the extent that there are different trends in the likelihood of unemployment and working practices by college and non-college educated (Ichino and Sanz de Galdeano 2005; Ramey and Ramey, 2010). ${ }^{17}$ Despite increases in the UK unemployment rate during the early to mid 1990s, college-educated mothers did not seem to suffer from unemployment shocks to a larger extent than non-college educated mothers over this period (see Evans 1998; OECD 2012 and the evidence presented in Figure 1). Similarly, available evidence does not support a decrease in the proportion of flexible working schedules, neither for the whole population nor for the college educated (EUROSTAT 2016).

\section{Safety Concerns}

The fact that college-educated parents may be more concerned about children's physical safety than non-college educated parents has been argued to be behind the positive education gradient in parental time investments in most developed countries, as college-educated parents spend more time accompanying and supervising their children (Ramey and Ramey, 2010). In order for this hypothesis to be able to explain the inverse U-shaped pattern in the education gradient in the UK, we estimate a model of safety concerns similar to that in Equation (1) to see if safety concerns for college and noncollege educated parents can be mapped to the trends in the education gradient in parental time investments shown in Table 2.

We use data from the International Crime Victims Survey (ICVS) for the years 1989, 1996, 2000, and 2004 (van Kesteren, 1989-2005), and construct dummy variables for fears of house burglary and feelings of unsafety on the street. As in Equation (1), our main independent variable is whether the

\footnotetext{
17 To have more time available for childcare, college-educated mothers may decide to opt out of the labour force to a greater extent than less-than college educated mothers (Goldin, 2006). In that case different trends in employment/working hours by education could also explain different trends in education gradients of time investments but this possibility does not invalidate our hypothesis as long as the decrease in working hours coincides with increases in competition for college.
} 
respondent completed more than the 12 years of education. We select all individuals aged 18-65 who are not student or retired. ${ }^{18}$

Trends in safety concerns for college and non-college educated individuals shown in Table 7 do not seem to match trends in the education gradient in parental time investments shown in Columns 1 and 5 Table $2 .{ }^{19}$ We find that the safety fears of college-educated individuals are consistently lower than those of their non-college educated counterparts throughout the period. More importantly, there is no sign of convergence, as college-educated individuals increasingly feel safer than non-college educated individuals over this period. For instance, safety fears about burglary of college educated women were 2 percentage points higher than those of their non-college educated counterparts in 1989, but by the mid 2000s they were 8 percentage points lower (Column 1 in Table 7). Similarly, the proportion of college educated women feeling very unsafe after dark was between 3 and 6 percentage points less than the corresponding proportion of non-college educated women throughout the mid 1990s-mid 2000s period (Column 2 in Table 7). We find similar trends for college and non-college educated men in Columns 3 and 4 in Table 7.

\section{$\underline{\text { Parenting Values }}$}

Ideals of good parenting may also differ by parenting education. Lareau (2003) and Putnam (2015) use ethnographic studies that show that college educated parents conform to the "concerted cultivation approach' which involves time intensive parenting strategies that involve discussion and dialogue, whereas children in working-class families are expected to entertain themselves and obey their parents. Here we use information from the European Values Study (1981, 1990, and 1999) and World Values Survey Data, 2005 (WVS, 2005-2007) for a sample of parents aged 18-65 (Appendix B). Using principal components analysis we construct a parenting values index that stresses independence and

\footnotetext{
18 See Appendix B for a description of how variables were constructed and Table A.11 in the Appendix A for descriptive statistics. Notice that survey years are not exactly coincident with those in MTUS data.

${ }^{19}$ We do not have information on whether respondents cohabit with children in the 2005 survey and therefore we select all women and men for the analysis, but results hold when using only the 1989, 1996, and 2000 surveys for just mothers and fathers.
} 
imagination over obedience and we interpret as indicative of the concerted cultivation approach (Lareau 2003, Doepke and Zilibotti, 2017). ${ }^{20}$ We estimate a model similar to that in Equation (1) with the parenting values index as the dependent variable.

The coefficients for the college educated dummy and its interactions with the year dummies in Table 8 show that trends in parenting values by parents with different educational attainment do not match the trends in the education gradient in time investments shown in Columns 1 and 5 in Table 2. Parenting values that stress independence over obedience were more popular among college educated mothers at the beginning of the period. Similarly to the trends in the education gradient in maternal time investments in Table 2, around the mid 1990s, the difference in the parenting value index between college and non-college educated mothers increased by 18 per cent. Yet, unlike the closing gap in maternal time investments documented in Column 1 in Table 2 after the mid 1990s, the gap on parenting values stressing independence over obedience between college and non-college educated remained for mothers. Moreover, the difference in the parenting value index between college and noncollege educated fathers continuously decreased from the early 1980s onwards.

\section{CONCLUSION}

Across the industrialized world college-educated parents invest more time in their children relative to non-college educated parents, particularly in human-capital enhancing activities. Yet, the reason for this education gradient in parental time investments is not well understood. In this paper we look at the UK to empirically test the theoretical hypothesis that competition for university places may be behind the trends in the education gradient in parental time investments.

\footnotetext{
${ }^{20}$ See Appendix B for a description of how variables were constructed and Tables A12 and A13 in Appendix A for descriptive statistics and factor loadings from the principal-components analysis. Notice that survey years are not exactly coincident with those in MTUS data.
} 
In order to properly answer this question, we put together a novel enrolment and average qualification time series from several administrative data sources since the 1970 s to construct measures of college competition over this period. Our research design exploits two different policy shocks that led to changes in the demand for university places and in the competition for college slots at elite universities in the 1980s and 1990s in the UK.

Our results suggest that increases in college competition can explain the temporal and spatial variation in the education gradient in parental time investments in the UK, as well as the type of time investments that college-educated parents and their children engage in. We first show that the education gradient closely followed college competition trends, sharply increasing from the mid 1980s to the mid 1990s and decreasing thereafter. We also show that college-educated parents in regions with high college-competitive pressures were the main contributors to the trends in the education gradient over the analyzed period. Conventional theories that unfold gradually cannot explain this inverse Ushape in the education gradient. 


\section{REFERENCES}

Abbott, A. and D. Leslie. "Recent Trends in Higher Education Applications and Acceptances." Education Economics, 12(1), 2004, 67-86.

Aguiar, M. and E. Hurst. "Measuring Trends in Leisure: The Allocation of Time Over Five Decades." Quarterly Journal of Economics, 122, 2007, 969-1006.

Attanasio, O. and Kaufmann, K. "Educational Choices, Subjective Expectations, and Credit Constraints," NBER Working Papers 15087, 2009.

Avery, C. and J. Levin. "Early Admissions at Selective Colleges." American Economic Review, 100(5), 2010, 2125-56.

Becker, G. "A Theory of the Allocation of Time.” Economic Journal, 75, 1965, 493-517.

Bhattacharya, D., S. Kanaya, and M. Stevens. "Are University Admissions Academically Fair?" Review of Economics and Statistics 2016 doi: 10.1162/REST_a_00618.

Bianchi, Suzanne M., John P. Robinson, and Melissa A. Milkie. Changing Rhythms of American Family Life. New York: Russell Sage Foundation, 2006.

Black, D.A., and J. A. Smith. 'Estimating Returns to College Quality with Multiple Proxies for Quality.' Journal of Labor Economics, 24(3), 2006, 701-728.

Black, S. E. and P.J. Devereaux. "Recent developments in intergenerational mobility." In: Handbook of Labor Economics, edited by O. Ashenfelter and D. Card. Amsterdam: Horth-Holland, 2011, 14871541

Blackaby, D H and D. N. Manning, "The North-South Divide: Questions of Existence and Stability?" Economic Journal, 100(401), 1990, 510-527.

Blanden, J. and M. Machin, M. "Educational inequality and the expansion of UK higher education." Scottish Journal of Political Economy, 51, 2004, 230-249.

Bound, J., B. Hershbein. and B. T. Long. "Playing the Admissions Game: Student Reactions to Increasing College Competition." Journal of Economic Perspectives 23(4), 2009, 119-46.

Bratti, M. "Does the choice of university matter? A study of the differences across UK universities in life sciences students' degree performance." Economics of Education Review, 21(5), 2002, 431443.

Clark, D. "Do Recessions Keep Students in School? The Impact of Youth Unemployment on Enrolment in Post-compulsory Education in England”. Economica, 78, 2011, 523-545.

Coe, R and P. Tymms. "Summary of research on changes in educational standards in the UK." In Educational Briefing Book 2008: IoD Policy Paper, edited by M. Harris. London: Institute of Directors, 2008.

Cunha, F. and J. Heckman. "The Technology of Skill Formation.” American Economic Review, 97(2), 2007, 31-47.

Cunha, F., Elo, I. and Culhane, J."Eliciting Maternal Expectations about the Technology of Cognitive 
Skill Formation." NBER Working Papers 19144, 2013.

Dearden, L., R. Fitzsimons, and G. Wyness. "The Impact of Tuition Fees and Support on University Participation in the UK." CEE Discussion Papers 0126, Centre for the Economics of Education, LSE, 2011.

Dillon E. W. and Smith J. A. "Determinants of the Match between Student Ability and College Quality" Journal of Labor Economics 2017 35:1, 45-66

Doepke, M. and M. Zilibotti. "Parenting With Style: Altruism and Paternalism in Intergenerational Preference Transmission, Econometrica, 2017, 85, 1331-1371.

European Values Study 1981-2008, Longitudinal Data File. GESIS Data Archive, Cologne, ZA4804 Data File Version 2.0.0, doi:10.4232/1.11005

Eurostat. Full-time and part-time employment by sex, age and educational attainment level http://ec.europa.eu/eurostat/data/database?node_code=edat_lfs_9907, 2016.

Evans, P. (1998). "Why has the female unemployment rate fallen so much in Britain?," Bank of England working papers 87, Bank of England.

Fiorini, M. and M. P. Keane. "How the Allocation of Children's Time Affects Cognitive and Noncognitive Development." Journal of Labor Economics 32(4), 2014, 787 - 836.

Fisher, K. and J. Gershuny. Multinational Time Use Study User's Guide and Documentation. Oxford, UK: Centre for Time Use Research, University of Oxford, 2013.

Gatenby, R. Comparison of Time Use Data from Pre-Coded Diaries and Fully-Written Diaries. London, UK: Office for National Statistics. http://www.timeuse.org/sites/ctur/files/public/ ctur_report/4965/gatenby_2003_light_vs_heavy.pdf, 2003.

Gershuny, J. and R. Smith. Report to the Central Statistical Office on the development of a simple diary schedule. OPCS Omnibus: review of the first six months, London: OPCS, 1995.

Gibbons, S. and A. Vignoles. "Geography, choice and participation in higher education in England." Regional Science and Urban Economics, 42(1-2), 2012, 98-113.

Gimenez-Nadal, J.I. and A. Sevilla. "Trends in time allocation: A cross-country analysis," European Economic Review, 56(6), 2012, 1338-1359.

Goldin, C. "The Quiet Revolution That Transformed Women's Employment, Education, and Family," American Economic Review, 96(2), 2006, 1-21.

Greenaway, D. and M. Haynes. "Funding Higher Education in The UK: The Role of Fees and Loans," Economic Journal 113(485), 2003, F150-F166.

Guryan, J., E. Hurst and M. Kearney. "Parental Education and Parental Time With Children," Journal of Economic Perspectives, Summer 2008: 23-46.

HEFCE. Supply and demand in higher education, HEFCE Consultation 01/62.http://webarchive.nationalarchives.gov.uk/20100202100434/http://www.hefce.ac.uk/pubs/hef ce/2001/01_62.htm, 2001.

Heckman, J. and S. Mosso."The Economics of Human Development and Social Mobility." Annual 
Review of Economics, 6(1), 2014, 689-733.

Higher Education Statistics Agency. Students in Higher Education Institutions. London, UK: Higher

Education Statistics Agency. https://www.hesa.ac.uk/pubs/students, 1994-2005.

Hoxby, C. M. "How the Changing Market Structure of U.S. Higher Education Explains College

Tuition." NBER Working Paper 6323, 1997.

Hoxby, C. M. "The Changing Selectivity of American Colleges". Journal of Economic Perspectives, 23(4), 2009, 95-118.

Hussain, I., S. McNally and S. Telhaj. "University Quality and Graduate Wages in the UK," IZA Discussion Papers 4043, 2009.

Ichino, A., L. Karabarbounis, and E. Moretti, E. "The political economy of intergenerational income mobility". Economic Inquiry, 49, 2011, 47-69.

Ichino, A. and A. Sanz-de-Galdeano. "Reconciling motherhood and work: evidence from time use data in three countries." In The Economics of Time Use, edited by Daniel S. Hamermesh and Gerard A. Pfann. Amsterdam: Elsevier, 2005, 263-288.

Jensen, R. "The (Perceived) Returns to Education and the Demand for Schooling." The Quarterly Journal of Economics, 125(2), 2010, 515-548.

Jerrim, J., A. Vignoles and R. Finnie. "University access for disadvantaged children: A comparison across English speaking countries." Higher Education 70, 2015, 903-921.

Lareau, A. Unequal Childhoods, Berkeley: University of California Press, 2003.

Leibowitz, A. (1975). "Education and the Allocation of Women's Time." In: Education, Income, and Human Behavior, edited by F. Thomas Juster. Boston: National Bureau of Economic Research, 1975, 171-198.

Machin S. and J. Van Reenen J. 'Wage Inequality, Changes in.' In The New Palgrave Dictionary of Economics, Second edition, edited by S. N. Durlauf and L. E. Blume. Palgrave Macmillan, http://www.dictionaryofeconomics.com/article?id=pde2008_C000551, doi: 10.1057/9780230226203.1808, 2008.

OECD. Education at a Glance 2011: OECD Indicators. http://www.oecd.org/education/school/educationataglance2011oecdindicators.htm, 2012.

Putnam, R. D. Our Kids: The American Dream in Crisis. New York: Simon and Schuster, 2015.

Ramey, G. and V. A. Ramey. "The Rug Rat Race."Brookings Papers on Economic Activity. Spring 2010, 129-176.

Richey, J. and A. Rosburg. "Changing roles of ability and education in U.S. intergenerational mobility." Economic Inquiry, 55, 2017, 187-201.

Robbins, L. (chair) Higher education. Report of the committee appointed by the Prime Minister under the chairmanship of Lord Robbins 1961-63. Cmnd. 2154. London: Her Majesty's Stationary Office, 1963.

Stafford, F., and Yeung, W. J. "The distribution of children's developmental resources." In The 
Economics of Time Use, edited by D. S. Hamermesh and A. P. Gerard. Amsterdam: Elsevier, 2005, 289-313.

Universities Statistical Record, Universities' Statistical Record, Undergraduate Records [computer file]. Colchester, Essex: UK Data Archive [distributor], June 1996. SN: 3456 http://dx.doi.org/10.5255/UKDA-SN-3456-1, 1972/73-1993/94.

van Kesteren, J.N. International Crime Victims Surveys - ICVS - 1989, 1992, 1996, 2000, 2005

Persistent Identifier: urn:nbn:nl:ui:13-wx0-h0o Data Archiving and Networked Services - DANS, 1989, 1992, 1996, 2000, 2005.

Walker, I. and Y. Zhu. "University Selectivity and the Graduate Wage Premium: Evidence from the UK," IZA Discussion Papers 10536, Institute for the Study of Labor (IZA), 2017.

Wiswall, M. and Zafar, B. "Determinants of College Major Choices: Identification from an Information Experiment." Review of Economic Studies, 2015, doi: 10.1093/restud/rdu044.

World Value Survey. (ICPSR 6160). Ann Arbor, MI: Inter-university Consortium for Political and Social Research, 1981, 1990, 1995, 2000, 2005.

Zhu, G. and G. Vural, "Inter-generational effect of parental time and its policy implications," Journal of Economic Dynamics and Control, 37(9), 2013, 1833-1851. 
FIGURE 1

\section{Trends in Overall Time Use by Parents by Educational Attainment}
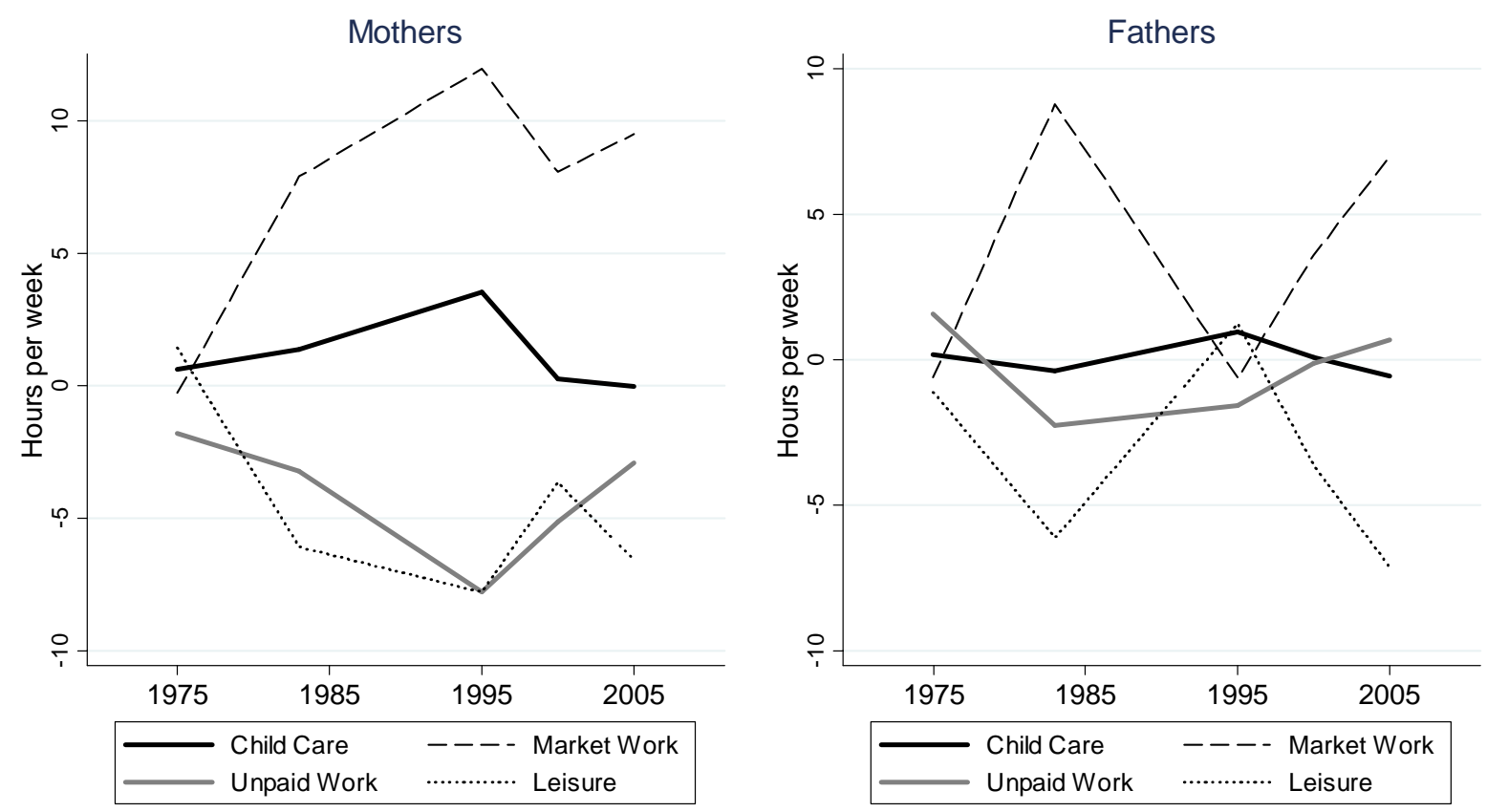

Notes: The graphs in this Figure plot the estimated coefficients $\beta_{1}+\boldsymbol{\beta}_{\mathbf{2}}$ in the equation $Y_{i t}=\beta_{1} H_{i t}+H_{i t} \mathbf{T}_{\mathbf{t}} \boldsymbol{\beta}_{\mathbf{2}}+\mathbf{X}_{\mathrm{it}} \boldsymbol{\beta}_{3}+\delta_{t}+\varepsilon_{i t}$. The dependent variable $Y_{i t}$ is hours per week spent on market work, unpaid work, leisure and personal care and total childcare. Market work includes all paid work and related commuting, unpaid work comprises housework, food preparation, shopping, and domestic travel, and leisure and personal care consists of any other uses of time, not previously included. In all specifications $H_{i t}$ is a dummy variable of parental education (=1 college educated), $\mathbf{T}_{\mathbf{t}}$ is a vector of dummies for the survey year, $\delta_{t}$ are survey-period fixed effects, $\mathrm{X}_{\mathrm{it}}$ include controls parents' ages, marital status, a quadratic in the number of children, and a vector of dummies to control for the day of the week the diary was reported, ref. 24-35 year-olds, Sunday), and $\varepsilon_{i t}$ is the error term clustered at the survey level. The samples include all mothers (fathers) 18-64 who are not students or retired, where mother is defined as having a child under the age of 18 in the house.

Source: MTUS (1974, 1983, 1995, 2000, 2005). 
FIGURE 2.

\section{Competition for College Admissions at Elite Universities and Education Gradients in Time Investments}
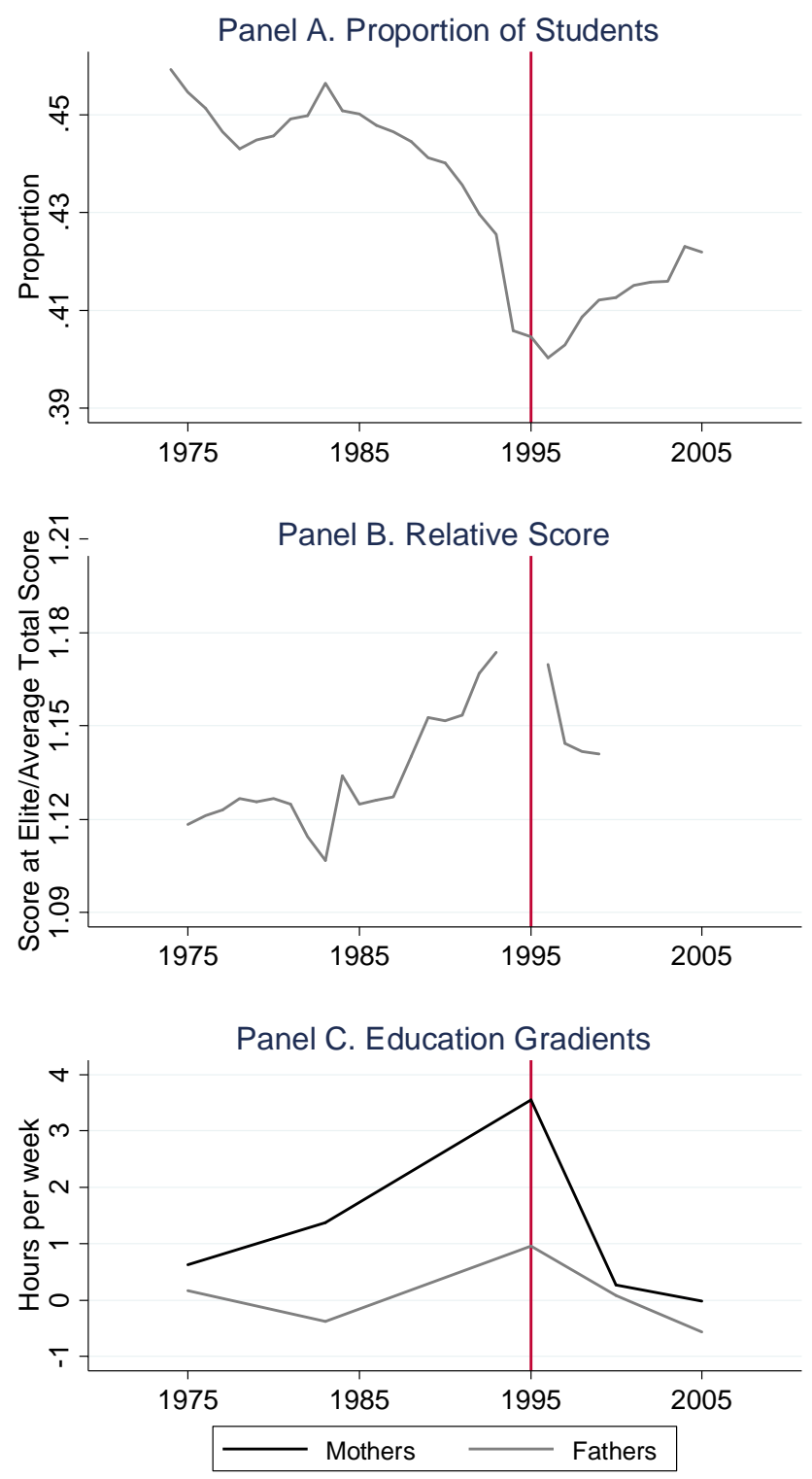

Note: Elite universities are the 17 founding members of the Russell Group in 1994: Birmingham, Bristol, Cambridge, Edinburgh, Glasgow, Imperial College London, Leeds, Liverpool, London School of Economics, Manchester, Newcastle, Nottingham, Oxford, Sheffield, Southampton, University College London, and Warwick. Panel A shows the proportion of full-time undergraduate students enrolled at elite universities out of the total number of students attending existing Higher Education institutions before the passage of the 1992 Further Education Act as offered in Column 3 of Table 4. Panel B shows the ratio of average scores of students enrolled at elite universities to average scores of all students as offered in Column 6 of Table 6 . Individual students' scores are calculated summing up scores from their 3 top A-level scores with A's gaining 10 points, B's, 8, C's, 6, D's, 4, and E's, 2 in USR and two points more, from 12 to 4, in THES. Panel A plots the coefficients for the college educated dummy and its interactions with the year dummies from Columns 1 and 5 of Table 2.

Source: MTUS (1974, 1983, 1995, 2000, 2005), University Statistical Records Microdata (1972-1993), Higher Education Statistical Agency (1994-2005) and Times Higher Education Supplement (1996-1999). 
FIGURE 3

\section{Competition for College Admissions at Elite Universities by Region}
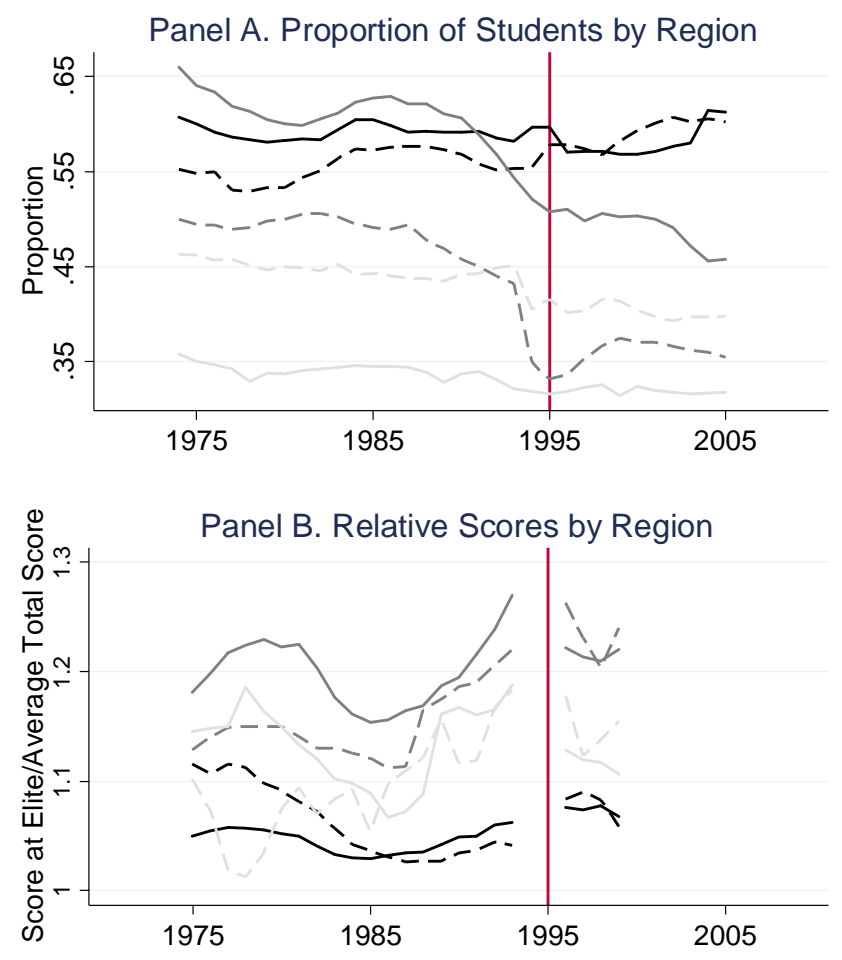

\begin{tabular}{|c|c|}
\hline North of England & ---- Midlands \\
East of England & ---- London \& South East \\
South West England ---- & Scotland
\end{tabular}

Note: Elite universities are the 17 founding members of the Russell Group in 1994: Birmingham, Bristol, Cambridge, Edinburgh, Glasgow, Imperial College London, Leeds, Liverpool, London School of Economics, Manchester, Newcastle, Nottingham, Oxford, Sheffield, Southampton, University College London, and Warwick. Panel A shows the proportion of full-time undergraduate students enrolled at elite universities out of the total number of students attending existing Higher Education institutions before the passage of the 1992 Further Education Act by region as offered in Table A.7. Panel B shows the ratio of average scores of students enrolled at elite universities to average scores of all students by region as offered in Table A.8. Individual students' scores are calculated summing up scores from their 3 top A-level scores with A's gaining 10 points, B's, 8, C's, 6, D's, 4, and E's, 2 in USR and two points more, from 12 to 4 , in THES.

Source: University Statistical Records Microdata (1972-1993), Higher Education Statistical Agency (1994-2005) and Times Higher Education Supplement (1996-1999). 
TABLE 1

Descriptive Statistics of Childcare time by education level. UK $(1974,1983,1995,2000,2005)$

\begin{tabular}{|c|c|c|c|c|c|c|c|c|c|c|}
\hline & \multicolumn{5}{|c|}{ Mothers } & \multicolumn{5}{|c|}{ Fathers } \\
\hline & 1974 & 1983 & 1995 & 2000 & 2005 & 1974 & 1983 & 1995 & 2000 & 2005 \\
\hline Less than college & $\begin{array}{l}1.55 \\
(3.4)\end{array}$ & $\begin{array}{l}2.67 \\
(4.5)\end{array}$ & $\begin{array}{l}7.37 \\
(9.2)\end{array}$ & $\begin{array}{l}4.45 \\
(6.6)\end{array}$ & $\begin{array}{c}7.55 \\
(11.8)\end{array}$ & $\begin{array}{l}0.42 \\
(2.0)\end{array}$ & $\begin{array}{l}0.92 \\
(2.9)\end{array}$ & $\begin{array}{c}3.31 \\
(11.8)\end{array}$ & $\begin{array}{l}1.72 \\
(4.2)\end{array}$ & $\begin{array}{c}4.35 \\
(10.6)\end{array}$ \\
\hline Some college or more & $\begin{array}{l}1.90 \\
(3.8)\end{array}$ & $\begin{array}{l}3.79 \\
(5.7)\end{array}$ & $\begin{array}{l}10.54 \\
(10.9)\end{array}$ & $\begin{array}{l}4.47 \\
(6.4)\end{array}$ & $\begin{array}{c}7.28 \\
(11.0)\end{array}$ & $\begin{array}{l}0.66 \\
(2.4)\end{array}$ & $\begin{array}{l}0.69 \\
(2.4)\end{array}$ & $\begin{array}{l}4.18 \\
(9.1)\end{array}$ & $\begin{array}{l}1.78 \\
(4.4)\end{array}$ & $\begin{array}{l}3.72 \\
(8.6)\end{array}$ \\
\hline Education gradient & $\begin{array}{l}0.35 \\
(0.3)\end{array}$ & $\begin{array}{l}1.12 \\
(0.3)\end{array}$ & $\begin{array}{l}3.17 \\
(2.1)\end{array}$ & $\begin{array}{l}0.02 \\
(0.3)\end{array}$ & $\begin{array}{l}-0.27 \\
(1.3)\end{array}$ & $\begin{array}{l}0.25 \\
(0.1)\end{array}$ & $\begin{array}{r}-0.23 \\
(0.3)\end{array}$ & $\begin{array}{l}0.87 \\
(2.4)\end{array}$ & $\begin{array}{l}0.05 \\
(0.2)\end{array}$ & $\begin{array}{l}-0.64 \\
(1.4)\end{array}$ \\
\hline
\end{tabular}

Notes: This table shows means and standard deviations of the dependent variable used in the analysis by survey year, as well as the education gradient (defined as the difference in total time in hours per week devoted to childcare by college and non college mothers/fathers) and its standard deviation. The samples include all mothers (all fathers) 18-64 who are not students or retired, where mother is defined as having a child under the age of 18 in the house. Sample weighting used.

Source: MTUS (1974-2005) 
TABLE 2

Trends in Parental Time Investments by Educational Attainment. UK (1974, 1983, 1995, 2000, 2005)

\begin{tabular}{|c|c|c|c|c|c|c|c|c|}
\hline \multirow{4}{*}{ year_1974 } & \multicolumn{4}{|c|}{ Mothers } & \multicolumn{4}{|c|}{ Fathers } \\
\hline & (1) & (2) & (3) & (4) & (5) & (6) & (7) & $(8)$ \\
\hline & Total Care & General & Teaching & Playing & Total Care & General & Teaching & Playing \\
\hline & $\begin{array}{c}-1.08 * * * \\
(0.048)\end{array}$ & & & & $\begin{array}{c}-0.52 * * * \\
(0.037)\end{array}$ & & & \\
\hline year_1983 & ref. & ref. & ref. & ref. & & ref. & ref. & ref. \\
\hline year_1995 & $\begin{array}{c}4.31 * * * \\
(0.070)\end{array}$ & & & & $\begin{array}{c}2.27 * * * \\
(0.057)\end{array}$ & & & \\
\hline year_2000 & $\begin{array}{l}1.63 * * * \\
(0.042)\end{array}$ & $\begin{array}{l}0.59 * * \\
(0.024)\end{array}$ & $\begin{array}{l}0.24 * * \\
(0.006)\end{array}$ & $\begin{array}{l}0.76^{* *} \\
(0.024)\end{array}$ & $\begin{array}{c}0.77 * * * \\
(0.045)\end{array}$ & $\begin{array}{l}0.25 * * \\
(0.009)\end{array}$ & $\begin{array}{l}0.13 * * \\
(0.002)\end{array}$ & $\begin{array}{l}0.38 * * \\
(0.022)\end{array}$ \\
\hline year_2005 & $\begin{array}{c}4.60 * * * \\
(0.119)\end{array}$ & & & & $\begin{array}{c}3.39 * * * \\
(0.031)\end{array}$ & & & \\
\hline College educated & $\begin{array}{l}1.31 * * * \\
(0.014)\end{array}$ & $\begin{array}{c}0.70^{*} \\
(0.071)\end{array}$ & $\begin{array}{l}0.17 * * \\
(0.005)\end{array}$ & $\begin{array}{l}0.42 * * \\
(0.018)\end{array}$ & $\begin{array}{c}-0.38 * * * \\
(0.076)\end{array}$ & $\begin{array}{l}-0.38 * * \\
(0.019)\end{array}$ & $\begin{array}{c}-0.01 \\
(0.013)\end{array}$ & $\begin{array}{c}-0.08 \\
(0.039)\end{array}$ \\
\hline College educated*year_1974 & $\begin{array}{c}-0.69 * * * \\
(0.042)\end{array}$ & & & & $\begin{array}{c}0.55 * * * \\
(0.063)\end{array}$ & & & \\
\hline College educated*year_1983 & & ref. & ref. & ref. & & ref. & ref. & ref. \\
\hline College educated*year_1995 & $\begin{array}{c}2.24 * * * \\
(0.070)\end{array}$ & & & & $\begin{array}{c}1.34 * * * \\
(0.187)\end{array}$ & & & \\
\hline College educated*year_2000 & $\begin{array}{c}-0.97 * * * \\
(0.019)\end{array}$ & $\begin{array}{l}-1.15^{* *} \\
(0.034)\end{array}$ & $\begin{array}{l}0.33 * * \\
(0.007)\end{array}$ & $\begin{array}{c}-0.13 \\
(0.028)\end{array}$ & $\begin{array}{l}0.46 * * \\
(0.109)\end{array}$ & $\begin{array}{c}0.44 * * * \\
(0.003)\end{array}$ & $\begin{array}{l}0.05 * * \\
(0.003)\end{array}$ & $\begin{array}{c}0.04 \\
(0.054)\end{array}$ \\
\hline College educated*year_2005 & $\begin{array}{c}-1.32 * * * \\
(0.037)\end{array}$ & & & & $\begin{array}{l}-0.19 * * \\
(0.066)\end{array}$ & & & \\
\hline Constant & $\begin{array}{l}2.61 * * \\
(0.740)\end{array}$ & $\begin{array}{c}2.36 \\
(0.524)\end{array}$ & $\begin{array}{c}-0.27 \\
(0.373)\end{array}$ & $\begin{array}{c}0.80 \\
(0.300)\end{array}$ & $\begin{array}{c}1.88 \\
(1.056)\end{array}$ & $\begin{array}{c}0.09 \\
(0.127)\end{array}$ & $\begin{array}{c}0.06 \\
(0.119)\end{array}$ & $\begin{array}{c}0.68 \\
(0.422)\end{array}$ \\
\hline Obs. & 5,935 & 3,203 & 3,203 & 3,203 & 4,831 & 2,241 & 2,241 & 2,241 \\
\hline
\end{tabular}

Notes: Each column comes from a different regression. The equation is $C T_{i t}=\beta_{1} H_{i t}+H_{i t} \mathbf{T}_{\mathbf{t}} \boldsymbol{\beta}_{\mathbf{2}}+\mathbf{X}_{\mathbf{i t}} \boldsymbol{\beta}_{\mathbf{3}}+\delta_{t}+\varepsilon_{i t}$. In all specifications $H_{i t}$ is a dummy variable of parental education ( $=1$ college educated), $\mathbf{T}_{\mathbf{t}}$ is a vector of dummies for the survey year, $\delta_{t}$ are survey-period fixed effects, and $\varepsilon_{i t}$ is the error term clustered at the survey level. In columns 1 and $5 C T_{i t}$ is total time in hours per week devoted to childcare; in columns 2 and $6 C T_{i t}$ is time in hours per week devoted to general care; in columns 3 and $7 C T_{i t}$ is time in hours per week devoted to teaching care; and in columns 4 and $8 C T_{i t}$ is time in hours per week devoted to playing care. $\mathrm{X}_{\text {it }}$ includes controls parents' ages, marital status, a quadratic in the number of children, and a vector of dummies to control for the day of the week the diary was reported, ref. 24-35 year-olds, Sunday), and the samples include mothers (fathers) 18-64 who are not students or retired, co-resident with at least a child 5-15 in the house and no children under 5 . The omitted year is labelled ref. in each column.

Source:MTUS (1974, 1983, 1995, 2000, 2005)

*** Significant at the 1 percent level.

** Significant at the 5 percent level. 
TABLE 3

Trends in Children's Time Investments by Educational Attainment. UK (1974, 1983, 2000)

\begin{tabular}{|c|c|c|c|}
\hline & $\begin{array}{c}\text { (1) } \\
\text { Homework }\end{array}$ & $\begin{array}{c}(2) \\
\text { Structured Act. }\end{array}$ & $\begin{array}{c}(3) \\
\text { Travel }\end{array}$ \\
\hline College educated & $\begin{array}{c}4.05 * * * \\
(0.046)\end{array}$ & $\begin{array}{l}3.51 * * \\
(0.763)\end{array}$ & $\begin{array}{l}0.46^{* *} \\
(0.085)\end{array}$ \\
\hline College educated*year_1974 & $\begin{array}{c}-3.97 * * * \\
(0.108)\end{array}$ & $\begin{array}{l}6.87 * * \\
(0.709)\end{array}$ & $\begin{array}{l}-0.68 * * \\
(0.075)\end{array}$ \\
\hline College educated*year_1983 & ref. & ref. & ref. \\
\hline College educated*year_2000 & $\begin{array}{l}0.27 * * \\
(0.041)\end{array}$ & $\begin{array}{c}0.50 \\
(0.858)\end{array}$ & $\begin{array}{l}-0.24 * \\
(0.071)\end{array}$ \\
\hline Constant & $\begin{array}{l}4.30 * * \\
(0.815)\end{array}$ & $\begin{array}{l}89.08 * * \\
(19.622)\end{array}$ & $\begin{array}{l}-4.80^{*} \\
(1.551)\end{array}$ \\
\hline Obs. & 3,333 & 3,333 & 3,333 \\
\hline
\end{tabular}

Notes: Each column comes from a different regression. The equation is $C T_{i t}=\beta_{1} H_{i t}+H_{i t} \mathbf{T}_{\mathbf{t}} \boldsymbol{\beta}_{\mathbf{2}}+\mathbf{X}_{\mathbf{i t}} \boldsymbol{\beta}_{\mathbf{3}}+\delta_{t}+\varepsilon_{i t}$. In all specifications $H_{i t}$ is a dummy variable of parental education ( $=1$ college educated), $\mathbf{T}_{\mathbf{t}}$ is a vector of dummies for the survey year, $\delta_{t}$ are survey-period fixed effects, and $\varepsilon_{i t}$ is the error term clustered at the survey level. In column 1 the dependent variable is children's homework time; in column 2 the dependent variable is children's time devoted to school and other classes; in column 3 the dependent variable is children's travel time. $\mathrm{X}_{\mathrm{it}}$ includes controls for children's ages, and a vector of dummies to control for the day of the week the diary was reported (ref. Sunday). The sample includes all children 14-17years-old. The omitted year is labelled ref. in each column.

Source:MTUS (1974, 1983, 2000)

*** Significant at the 1 percent level.

** Significant at the 5 percent level. 
TABLE 4

Competition for College Slots at Elite Universities (1974-2005).

\begin{tabular}{|c|c|c|c|c|c|c|}
\hline \multirow{3}{*}{ Year } & \multicolumn{3}{|c|}{ Enrolment Data } & \multicolumn{3}{|c|}{ Scores Data } \\
\hline & $(1)$ & $(2)$ & (3) & (4) & (5) & (6) \\
\hline & $\begin{array}{l}\text { Enrolment } \\
\text { at Elite and Non-elite }\end{array}$ & $\begin{array}{l}\text { Enrolment } \\
\text { at Elite }\end{array}$ & $\begin{array}{l}\text { Proportion } \\
\text { at Elite }\end{array}$ & $\begin{array}{l}\text { Average Scores } \\
\text { at Elite and Non-elite }\end{array}$ & $\begin{array}{l}\text { Average Scores } \\
\text { at Elite }\end{array}$ & $\begin{array}{l}\text { Relative } \\
\text { Scores }\end{array}$ \\
\hline 1974 & 214,746 & 98,636 & 0.459 & 16.58 & 18.58 & 1.121 \\
\hline 1975 & 224,166 & 101,915 & 0.455 & 16.55 & 18.51 & 1.118 \\
\hline 1976 & 234,773 & 105,968 & 0.451 & 16.56 & 18.57 & 1.121 \\
\hline 1977 & 245,798 & 109,777 & 0.447 & 16.67 & 18.72 & 1.123 \\
\hline 1978 & 254,058 & 112,595 & 0.443 & 16.70 & 18.82 & 1.127 \\
\hline 1979 & 261,093 & 116,195 & 0.445 & 16.82 & 18.94 & 1.126 \\
\hline 1980 & 267,566 & 119,305 & 0.446 & 17.01 & 19.17 & 1.127 \\
\hline 1981 & 270,168 & 121,348 & 0.449 & 17.36 & 19.53 & 1.125 \\
\hline 1982 & 268,085 & 120,604 & 0.450 & 17.66 & 19.69 & 1.115 \\
\hline 1983 & 263,053 & 120,103 & 0.457 & 18.12 & 20.05 & 1.107 \\
\hline 1984 & 266,352 & 120,098 & 0.451 & 17.90 & 20.29 & 1.134 \\
\hline 1985 & 267,953 & 120,683 & 0.450 & 18.13 & 20.39 & 1.125 \\
\hline 1986 & 271,848 & 121,778 & 0.448 & 18.10 & 20.39 & 1.126 \\
\hline 1987 & 276,462 & 123,509 & 0.447 & 17.93 & 20.21 & 1.127 \\
\hline 1988 & 286,016 & 127,194 & 0.445 & 17.53 & 19.98 & 1.140 \\
\hline 1989 & 301,870 & 133,206 & 0.441 & 17.23 & 19.86 & 1.153 \\
\hline 1990 & 317,777 & 139,921 & 0.440 & 17.17 & 19.78 & 1.152 \\
\hline 1991 & 341,616 & 148,825 & 0.436 & 17.11 & 19.73 & 1.153 \\
\hline 1992 & 371,638 & 159,729 & 0.430 & 16.58 & 19.35 & 1.167 \\
\hline 1993 & 402,069 & 171,162 & 0.426 & 16.17 & 18.98 & 1.174 \\
\hline 1994 & 426,283 & 173,058 & 0.406 & & & \\
\hline 1995 & 441,601 & 178,689 & 0.405 & & & \\
\hline 1996 & 461,565 & 184,775 & 0.400 & & & \\
\hline 1997 & 475,868 & 191,755 & 0.403 & 19.29 & 22.57 & 1.170 \\
\hline 1998 & 485,911 & 198,646 & 0.409 & 20.13 & 23.04 & 1.144 \\
\hline 1999 & 486,250 & 200,430 & 0.412 & 20.36 & 23.24 & 1.142 \\
\hline 2000 & 490,060 & 202,220 & 0.413 & 20.29 & 23.14 & 1.141 \\
\hline 2001 & 509,345 & 211,460 & 0.415 & & & \\
\hline 2002 & 532,385 & 221,410 & 0.416 & & & \\
\hline 2003 & 549,350 & 228,545 & 0.416 & & & \\
\hline 2004 & 564,755 & 238,985 & 0.423 & & & \\
\hline 2005 & 575,090 & 242,700 & 0.422 & & & \\
\hline $1974-2005$ & $11,605,570$ & $4,965,224$ & 0.428 & 17.19 & 19.48 & 1.133 \\
\hline
\end{tabular}

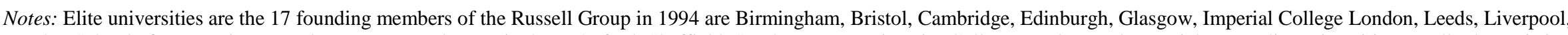

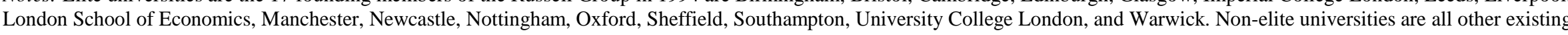

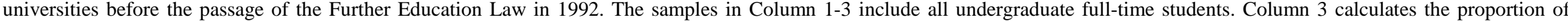

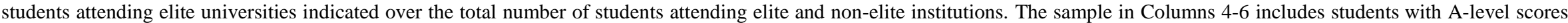

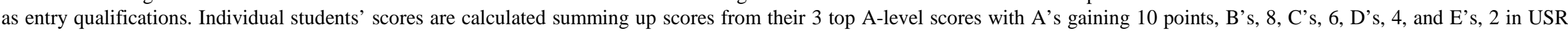
and two points more, from 12 to 4, in THES. Column 6 shows the ratio of average scores of students enrolled at elite universities to average scores at elite and non-elite universities.

Source: University Statistical Records Microdata (1972-1993) and Higher Education Statistical Agency (1994-2005) and Times Higher Education Supplement (1996-1999). 
TABLE 5

Trends in Parental Time Investments by Educational Attainment and Region. UK (1974, 1983, 1995, 2000, 2005)

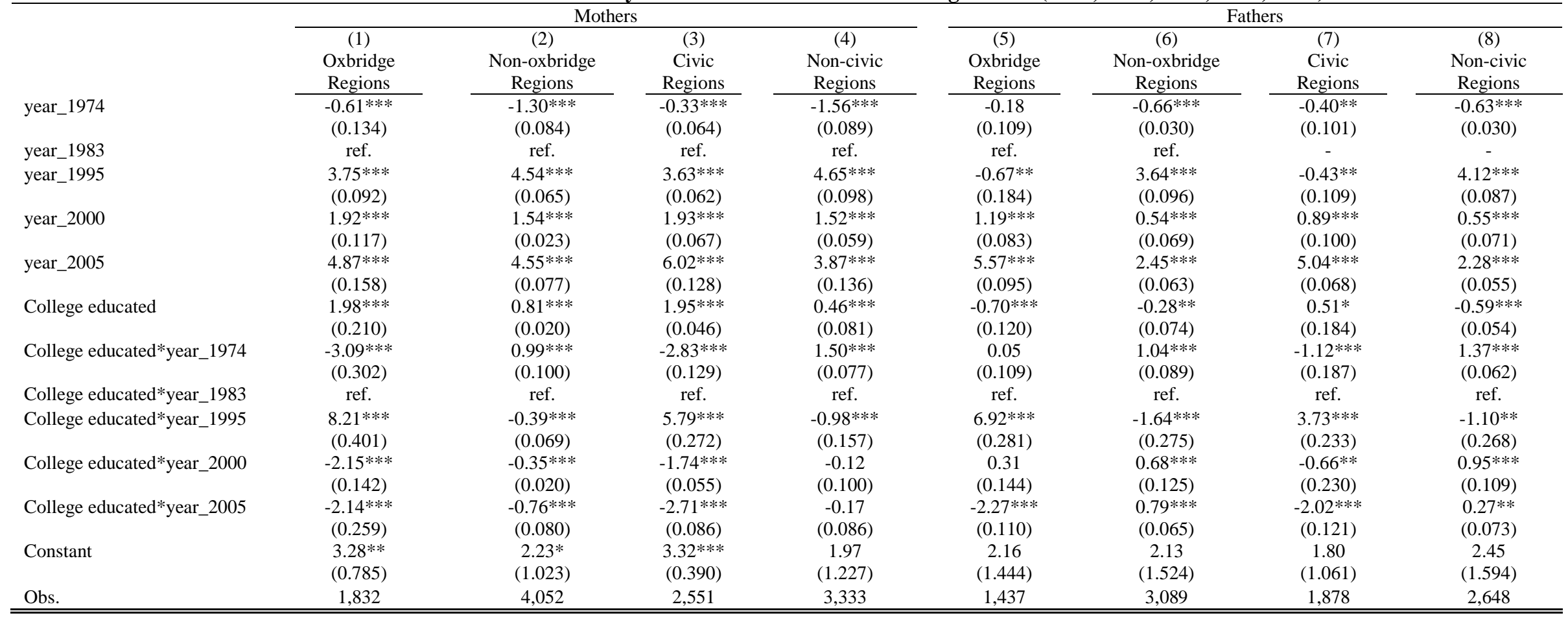

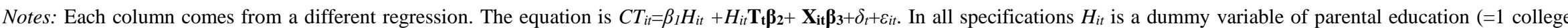

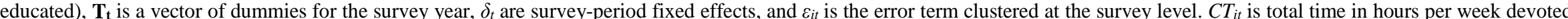

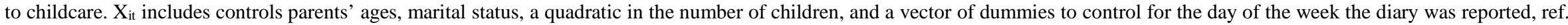

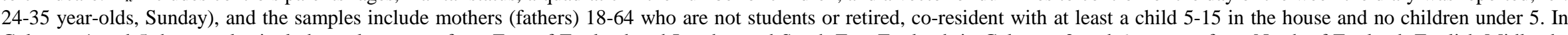

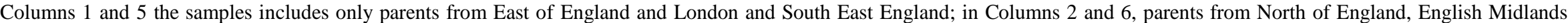

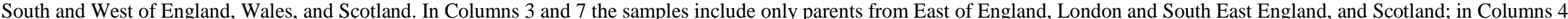
and 8, parents from North of England English Midlands, South and West of England, and Wales. The omitted year is labelled ref. in each column.

Source:MTUS (1974, 1983, 1995, 2000, 2005)

*** Significant at the 1 percent level. ** Significant at the 5 percent level. 
TABLE 6

Trends in College Education Gradients-Alternative Explanations: Selection Effects, Compositional Effects, Money-Budget Constraints. UK (1974, 1983, 1995, 2000, 2005)

\begin{tabular}{|c|c|c|c|c|c|c|}
\hline & \multicolumn{2}{|c|}{ Selection Effects } & \multicolumn{2}{|c|}{ Compositional Effects } & \multicolumn{2}{|c|}{ Money-Budget Constraints } \\
\hline & $\begin{array}{c}(1) \\
\text { Mothers }\end{array}$ & $\begin{array}{c}\text { (2) } \\
\text { Fathers }\end{array}$ & $\begin{array}{c}\text { (3) } \\
\text { Mothers }\end{array}$ & $\begin{array}{c}\text { (4) } \\
\text { Fathers }\end{array}$ & $\begin{array}{c}\text { (5) } \\
\text { Mothers }\end{array}$ & $\begin{array}{c}\text { (6) } \\
\text { Fathers }\end{array}$ \\
\hline College educated & $\begin{array}{c}0.09 \\
(0.091)\end{array}$ & $\begin{array}{c}-0.15 * * * \\
(0.017)\end{array}$ & $\begin{array}{l}1.05 * * * \\
(0.077)\end{array}$ & $\begin{array}{c}0.00 \\
(0.064)\end{array}$ & $\begin{array}{l}1.21 * * * \\
(0.045)\end{array}$ & $\begin{array}{l}-0.42 * * \\
(0.112)\end{array}$ \\
\hline College educated *year_1974 & $\begin{array}{l}0.08 * * \\
(0.019)\end{array}$ & $\begin{array}{c}0.27 * * * \\
(0.044)\end{array}$ & $\begin{array}{c}-0.84 * * * \\
(0.022)\end{array}$ & $\begin{array}{l}0.37 * * \\
(0.085)\end{array}$ & $\begin{array}{c}-0.81 * * * \\
(0.088)\end{array}$ & $\begin{array}{l}0.49 * * \\
(0.129)\end{array}$ \\
\hline College educated *year_1983 & & & & & & \\
\hline College educated *year_1995 & $\begin{array}{c}0.23 * * * \\
(0.021)\end{array}$ & $\begin{array}{l}0.16^{* *} \\
(0.040)\end{array}$ & $\begin{array}{c}2.49 * * * \\
(0.126)\end{array}$ & $\begin{array}{c}0.96 * * * \\
(0.144)\end{array}$ & $\begin{array}{c}2.19 * * * \\
(0.075)\end{array}$ & $\begin{array}{c}1.34 * * * \\
(0.187)\end{array}$ \\
\hline College educated *year_2000 & $\begin{array}{c}-0.31 * * * \\
(0.044)\end{array}$ & $\begin{array}{c}-0.06 * * * \\
(0.011)\end{array}$ & $\begin{array}{c}-0.72 * * * \\
(0.070)\end{array}$ & $\begin{array}{c}0.08 \\
(0.080)\end{array}$ & $\begin{array}{c}-0.93 * * * \\
(0.038)\end{array}$ & $\begin{array}{l}0.45^{* *} \\
(0.128)\end{array}$ \\
\hline College educated *year_2005 & $\begin{array}{c}-1.01 * * * \\
(0.030)\end{array}$ & $\begin{array}{c}-0.77 * * * \\
(0.019)\end{array}$ & $\begin{array}{c}-1.07 * * * * \\
(0.084)\end{array}$ & $\begin{array}{c}-0.57 * * * * \\
(0.090)\end{array}$ & $\begin{array}{c}-1.29 * * * \\
(0.040)\end{array}$ & $\begin{array}{c}-0.19 \\
(0.090)\end{array}$ \\
\hline Income 2 & & & & & $\begin{array}{c}-0.51 * * \\
(0.146)\end{array}$ & $\begin{array}{c}0.01 \\
(0.142)\end{array}$ \\
\hline Income 3 & & & & & $\begin{array}{c}0.14 \\
(0.299) \\
\end{array}$ & $\begin{array}{c}0.20 \\
(0.255) \\
\end{array}$ \\
\hline constant & $\begin{array}{c}1.11^{*} \\
(0.441)\end{array}$ & $\begin{array}{c}0.19 \\
(0.185)\end{array}$ & $\begin{array}{l}2.62 * * \\
(0.744)\end{array}$ & $\begin{array}{c}1.81 \\
(1.032)\end{array}$ & $\begin{array}{l}2.83^{* * *} \\
(0.750)\end{array}$ & $\begin{array}{c}1.85 \\
(1.033)\end{array}$ \\
\hline Obs. & 15,014 & 12,862 & 5,935 & 4,568 & 5,935 & 4,568 \\
\hline
\end{tabular}

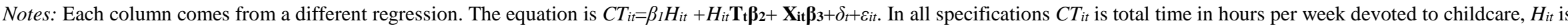

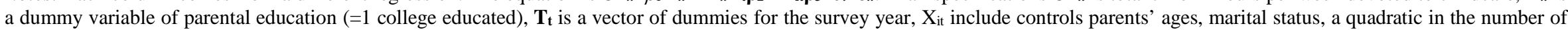

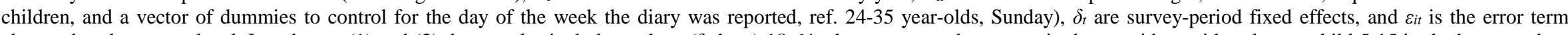

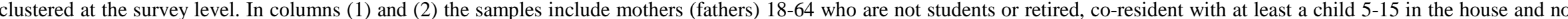

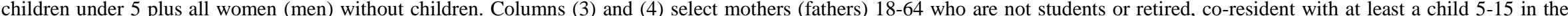

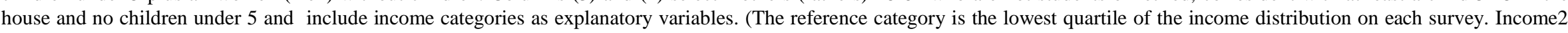

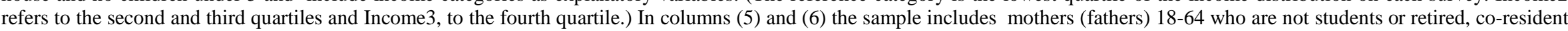

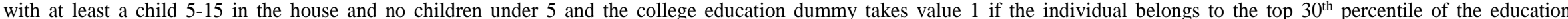
distribution. Standard errors in parentheses.* significant at 10\%** significant at 5\%; *** significant at $1 \%$.

Source: MTUS (1974, 1983, 1995, 2000, 2005) 
TABLE 7

Trends in Women and Men's Safety Concerns by Educational Attainment. UK $(1989,1996,2000,2005)$

\begin{tabular}{|c|c|c|c|c|}
\hline & \multicolumn{2}{|c|}{ Female } & \multicolumn{2}{|c|}{ Male } \\
\hline & (1) & $(2)$ & (3) & $(4)$ \\
\hline & Fears of house burglary & $\begin{array}{c}\text { Feelings of unsafety } \\
\text { on the streets }\end{array}$ & Fears of house burglary & $\begin{array}{c}\text { Feelings of unsafety } \\
\text { on the streets }\end{array}$ \\
\hline & ref. & & ref. & \\
\hline \multirow{2}{*}{ year_1996 } & $0.09 * * *$ & ref. & $0.02 * *$ & ref. \\
\hline & $(0.003)$ & & $(0.007)$ & \\
\hline \multirow[t]{2}{*}{ year_2000 } & $0.02 * * *$ & $-0.03 * * *$ & $-0.02 *$ & $-0.02 * * *$ \\
\hline & $(0.002)$ & $(0.002)$ & $(0.006)$ & $(0.001)$ \\
\hline \multirow[t]{2}{*}{ year_2004_5 } & $0.09 * * *$ & $0.02 * * *$ & -0.01 & $0.04 * * *$ \\
\hline & $(0.002)$ & $(0.001)$ & $(0.007)$ & $(0.000)$ \\
\hline \multirow[t]{2}{*}{ College educated } & $0.02 * * *$ & $-0.06 * * *$ & $0.01 *$ & $-0.02 * * *$ \\
\hline & $(0.002)$ & $(0.001)$ & $(0.003)$ & $(0.001)$ \\
\hline College educated $* 1989$ & ref. & & ref. & \\
\hline \multirow[t]{2}{*}{ College educated $* 1996$} & $-0.04 * * *$ & ref. & $-0.07 * * *$ & ref. \\
\hline & $(0.001)$ & & $(0.002)$ & \\
\hline \multirow[t]{2}{*}{ College educated $* 2000$} & $-0.05 * * *$ & $0.03 * * *$ & $-0.03 * * *$ & $0.01 *$ \\
\hline & $(0.001)$ & $(0.002)$ & $(0.001)$ & $(0.002)$ \\
\hline \multirow[t]{2}{*}{ College educated $* 2004 \_5$} & $-0.10 * * *$ & -0.00 & $-0.04 * * *$ & $-0.05 * * *$ \\
\hline & $(0.002)$ & $(0.002)$ & $(0.004)$ & $(0.002)$ \\
\hline \multirow[t]{2}{*}{ Constant } & $0.08 * * *$ & $0.15 * *$ & $0.06 * * *$ & $0.04 * * *$ \\
\hline & $(0.005)$ & $(0.027)$ & $(0.010)$ & $(0.003)$ \\
\hline Obs. & 7469 & 4838 & 6331 & 4067 \\
\hline
\end{tabular}

Notes: Each column comes from a different regression. The equation is $Y_{i t}=\beta_{1} H_{i t}+H_{i t} \mathbf{T}_{\mathbf{t}} \boldsymbol{\beta}_{\mathbf{2}}+\mathbf{X}_{\mathbf{i t}} \boldsymbol{\beta}_{\mathbf{3}}+\delta_{t}+\varepsilon_{i t}$. In all specifications $H_{i t}$ is a dummy variable of educational attainment ( $=1$ college educated), $\mathbf{T}_{\mathbf{t}}$ is a vector of dummies for the survey year, $\mathrm{X}_{\mathrm{it}}$ include controls for individuals' ages (ref. 24-35 year-olds), $\delta_{t}$ are survey-period fixed effects, and $\varepsilon_{i t}$ is the error term clustered at the survey level. In columns (1) and (3) $Y_{i t}$ is the likelihood of respondents' house being burgled in the coming year (1=very likely) and in columns (2) and (4) $Y_{i t}$ is an indicator of whether they feel unsafe when walking alone in their area after dark (1=very unsafe). The samples include all women (men) 18-64 who are not students or retired (no information on number of children for 2005 but results similar when selecting parents). Standard errors in parentheses. $*$ significant at $10 \% * *$ significant at $5 \%$; *** significant at $1 \%$.

Source: International Crime Victims Survey Data, 1989, 1996, 2000, 2005. 
TABLE 8

Trends in Parenting Values by Educational Attainment $(1981,1990,1999,2005)$

\begin{tabular}{|c|c|c|}
\hline & $\begin{array}{c}(1) \\
\text { Mothers }\end{array}$ & $\begin{array}{c}(2) \\
\text { Fathers }\end{array}$ \\
\hline year_1981 & ref. & ref. \\
\hline year_1990 & $\begin{array}{c}0.40 * * * \\
(0.008)\end{array}$ & $\begin{array}{c}0.41 * * * \\
(0.008)\end{array}$ \\
\hline year_1999 & $\begin{array}{c}0.61 * * * \\
(0.005)\end{array}$ & $\begin{array}{c}0.85 * * * \\
(0.012)\end{array}$ \\
\hline year_2005 & $\begin{array}{c}0.72 * * * \\
(0.020)\end{array}$ & $\begin{array}{c}1.04 * * * \\
(0.014)\end{array}$ \\
\hline College educated & $\begin{array}{c}0.11^{* * * *} \\
(0.009)\end{array}$ & $\begin{array}{c}0.60 * * * \\
(0.005)\end{array}$ \\
\hline College educated $* 1981$ & ref. & ref. \\
\hline College educated $* 1990$ & $\begin{array}{c}0.13 * * * \\
(0.007)\end{array}$ & $\begin{array}{c}-0.27 * * * * \\
(0.010)\end{array}$ \\
\hline College educated $* 1999$ & $\begin{array}{c}0.13 * * * \\
(0.008)\end{array}$ & $\begin{array}{c}-0.55^{* * * *} \\
(0.008)\end{array}$ \\
\hline College educated $* 2005$ & $\begin{array}{c}0.10^{* * * *} \\
(0.012)\end{array}$ & $\begin{array}{c}-0.59 * * * \\
(0.011)\end{array}$ \\
\hline Constant & $\begin{array}{c}-0.37 * * * * \\
(0.020)\end{array}$ & $\begin{array}{c}-0.60 \text { **** } \\
(0.059)\end{array}$ \\
\hline Obs. & 1179 & 832 \\
\hline
\end{tabular}

Notes: Each column comes from a different regression. The equation is $Y_{i t}=\beta_{1} H_{i t}+H_{i t} \mathbf{T}_{\mathbf{t}} \boldsymbol{\beta}_{\mathbf{2}}+\mathbf{X}_{\mathbf{i t}} \boldsymbol{\beta}_{3}+\delta_{t}+\varepsilon_{i t}$. In all specifications $H_{i t}$ is a dummy variable of parental education ( $=1$ college educated), $\mathbf{T}_{\mathbf{t}}$ is a vector of dummies for the survey year, $X_{\text {it }}$ include controls for parents' ages and marital status (ref. 24-35 year-olds), $\delta_{t}$ are survey-period fixed effects, and $\varepsilon_{i t}$ is the error term clustered at the survey level. The dependent variable $Y_{i t}$ is a composite measure of child-rearing values computed applying principal component analysis to the respondents' rankings on the qualities that children can be encouraged to learn at home from the following list: independence; hard work; feeling of responsibility; tolerance and respect; thrift, saving money and things; determination, perseverance; religious faith; and obedience. The samples include all mothers (fathers) 18-64 who are not students or retired. Standard errors in parentheses. * significant at $10 \% * *$ significant at $5 \%$; *** significant at $1 \%$.

Source: European Values Study (1981, 1990, and 1999) and World Values Survey Data, 2005. 


\section{Appendix A}

Figures and Tables

FIGURE A.1.

Enrolment at Different Types Higher Education Institutions

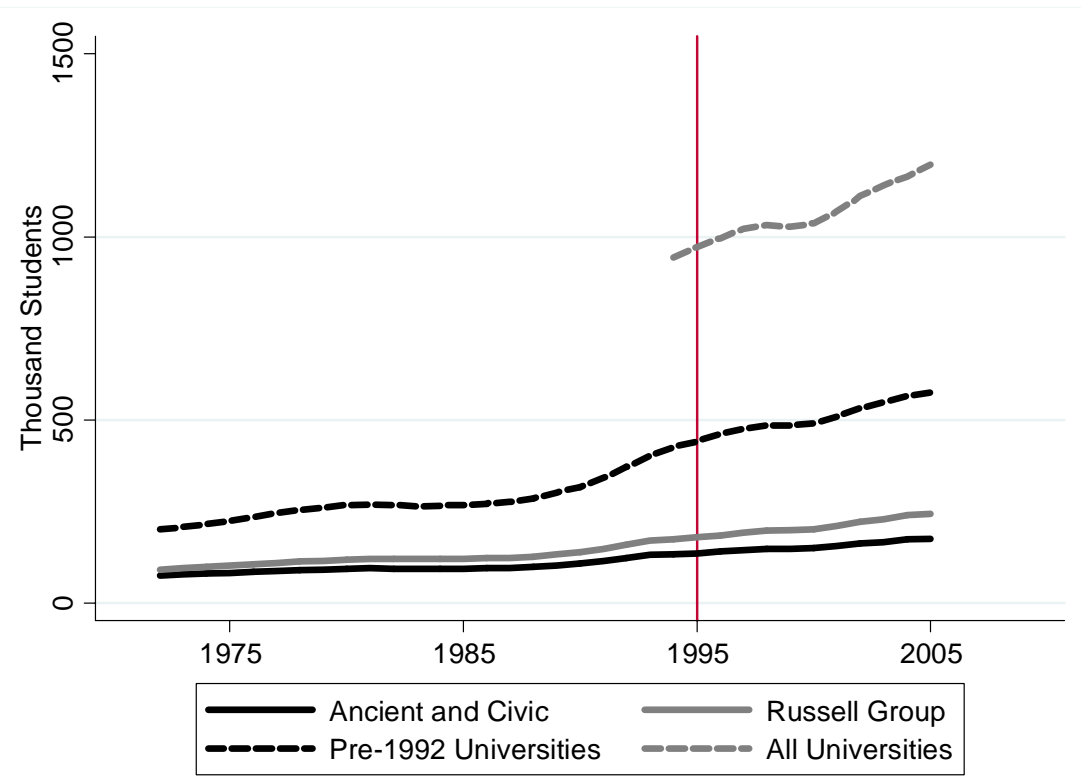

Note: The figure shows total full-time undergraduate students enrolled at elite and non-elite universities as offered in Columns 1, 2, 5, and 8 of Table A.8. Ancient and civic Universities are Oxford, Cambridge, St. Andrews, Glasgow, Aberdeen, and Edinburgh, all founded in the Middle Ages, and Birmingham, Liverpool, Manchester, Leeds, Sheffield, and Bristol, founded in the major industrial cities of England before World War I. The 17 founding members of the Russell Group in 1994 are Birmingham, Bristol, Cambridge, Edinburgh, Glasgow, Imperial College London, Leeds, Liverpool, London School of Economics, Manchester, Newcastle, Nottingham, Oxford, Sheffield, Southampton, University College London, and Warwick. Pre-1992 universities exclude those polytechnics granted university status by the 1992 Further and Higher Education Act and any university founded afterwards.

Source: University Statistical Records Microdata (1972-1993) and Higher Education Statistical Agency (1994-2005). 
TABLE A.1

Description of Time Use Surveys

\begin{tabular}{cccccccc}
\hline Year & Age & $\begin{array}{c}\text { Diary } \\
\text { days }\end{array}$ & $\begin{array}{c}\text { Multi- } \\
\text { member }\end{array}$ & $\begin{array}{c}\text { Time } \\
\text { interval }\end{array}$ & $\begin{array}{c}\text { Original sample } \\
\text { size }\end{array}$ & $\begin{array}{c}\text { Main analysis } \\
\text { sample size }\end{array}$ & $\begin{array}{c}\text { Children } \\
\text { analysis sample } \\
\text { size }\end{array}$ \\
\hline 1974 & $5+$ & 7 & Yes & 30 min. & 19490 & 4265 & 1412 \\
1983 & $14+$ & 7 & Yes & 15 min. & 9206 & 2082 & 812 \\
1995 & $16+$ & 1 & No & 15 min. & 1906 & 281 & $:$ \\
2000 & $8+$ & 2 & Yes & 10 min. & 19400 & 3687 & 1279 \\
2005 & $16+$ & 1 & No & 10 min. & 19400 & 688 & $:$ \\
\hline \hline
\end{tabular}

Notes: The column age refers to the age of the youngest person to fill a diary, not the youngest person in the household.

Source:MTUS (1983-2000) 
TABLE A.2

Activities in Total Time Investments, General Care, Teaching Care, and Playing Care. UK (1983, 2000)

\begin{tabular}{|c|c|c|c|}
\hline Measure & Description & 1983 Survey & 2000 Survey \\
\hline Parental Time Investments & childcare & All & All \\
\hline \multirow[t]{9}{*}{ General Care } & $\begin{array}{l}\text { physical, medical } \\
\text { child }\end{array}$ & 1101 Feed and food preparation for babies and children & 3800 Unspecified childcare \\
\hline & $\begin{array}{l}\text { care, supervise, } \\
\text { accompany, other }\end{array}$ & 1102 Wash, change babies & 3810 Unspecified physical care and supervision \\
\hline & child care & 1103 Put children to bed/get them up & 3811 Feeding the child \\
\hline & & 1104 Babysit other people's children & 3819 Other specified physical care \\
\hline & & 1105 Other care of babies & 4270 Unspecified childcare as help \\
\hline & & 1106 Medical care of babies, children \& adults & 4271 Physical child care as help \\
\hline & & 1109 Supervising children & 3840 Accompanying child \\
\hline & & 1110 Other care of children & 3890 Other specified childcare \\
\hline & & 1111 Childcare-unspecified & $\begin{array}{l}4274 \text { Accompany child as help } \\
4279 \text { Other specified childcare as help }\end{array}$ \\
\hline Teaching Care & $\begin{array}{l}\text { teach, help with } \\
\text { homework }\end{array}$ & 1108 Help children with homework & $\begin{array}{l}3820 \text { Teaching the child } \\
4272 \text { Teaching a child as help }\end{array}$ \\
\hline \multirow[t]{2}{*}{ Playing Care } & read to, talk or play & $\begin{array}{l}1107 \text { Reading to, or playing with babies, children \& } \\
\text { adults }\end{array}$ & 3830 Reading, playing and talking with child \\
\hline & with child & & $4273 \mathrm{Read} /$ talk to child as help \\
\hline
\end{tabular}

Source:MTUS (1983-2000) 
TABLE A.3

Activities in Children's Time Use. UK $(1974,1983,2000)$ and US $(1985,2000)$.

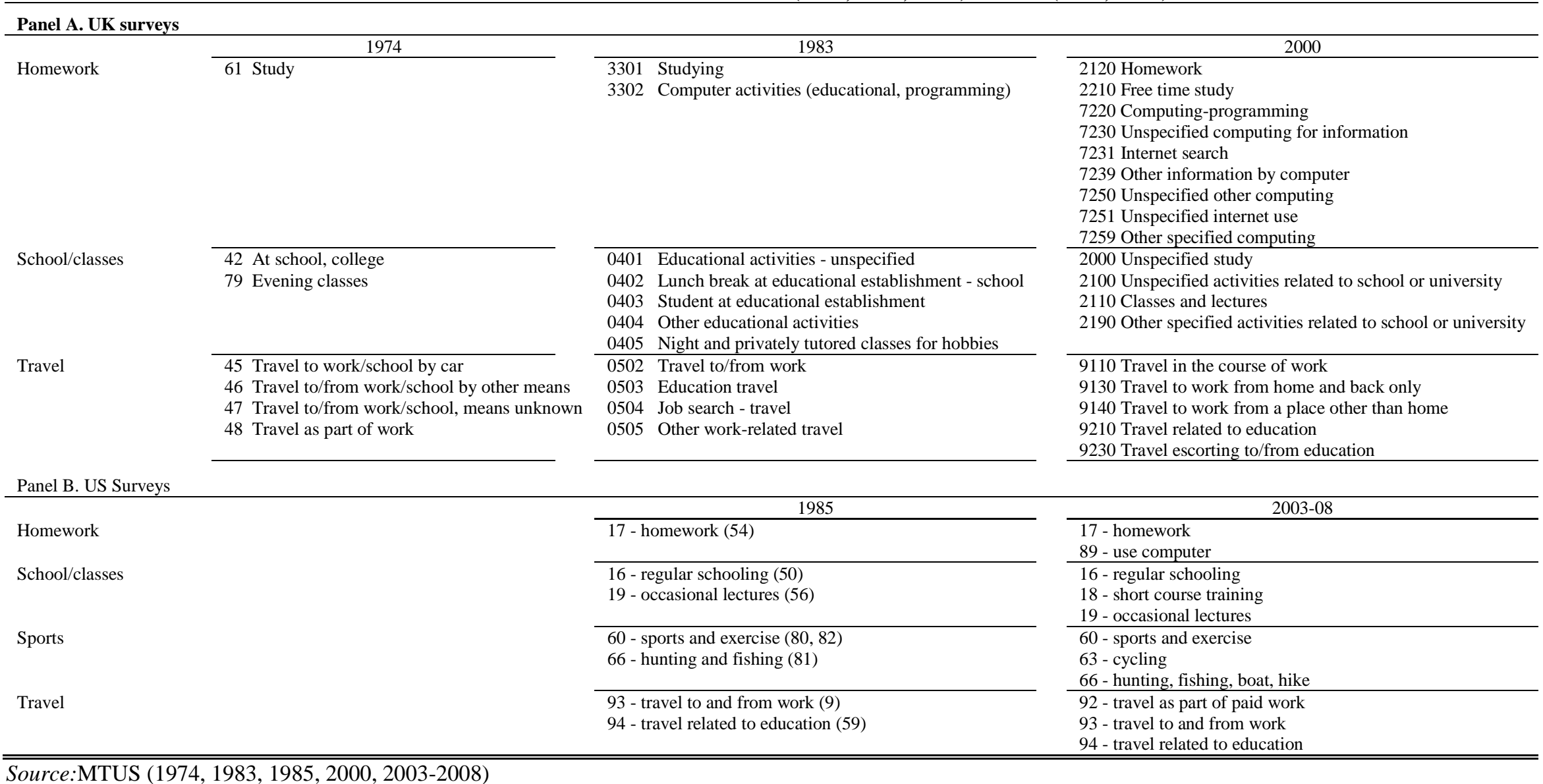


TABLE A. 4

Descriptive Statistics of Controls. UK $(1974,1983,1995,2000,2005)$

\begin{tabular}{|c|c|c|c|c|c|c|c|c|c|c|}
\hline & \multicolumn{5}{|c|}{ Mothers } & \multicolumn{5}{|c|}{ Fathers } \\
\hline & 1974 & 1983 & 1995 & 2000 & 2005 & 1974 & 1983 & 1995 & 2000 & 2005 \\
\hline \multirow[t]{2}{*}{ Some college or more } & 0.08 & 0.17 & 0.14 & 0.27 & 0.24 & 0.10 & 0.16 & 0.26 & 0.25 & 0.32 \\
\hline & $(0.3)$ & $(0.4)$ & $(0.3)$ & $(0.4)$ & $(0.4)$ & $(0.3)$ & $(0.4)$ & $(0.4)$ & $(0.4)$ & $(0.5)$ \\
\hline \multirow[t]{2}{*}{ Age $18-24$} & 0.11 & 0.10 & 0.03 & 0.06 & 0.04 & 0.18 & 0.13 & 0.06 & 0.10 & 0.10 \\
\hline & $(0.3)$ & $(0.3)$ & $(0.2)$ & $(0.2)$ & $(0.2)$ & $(0.4)$ & $(0.3)$ & $(0.2)$ & $(0.3)$ & $(0.3)$ \\
\hline \multirow[t]{2}{*}{ Age $25-34$} & 0.18 & 0.15 & 0.25 & 0.19 & 0.19 & 0.10 & 0.10 & 0.13 & 0.12 & 0.08 \\
\hline & $(0.4)$ & $(0.4)$ & $(0.4)$ & $(0.4)$ & $(0.4)$ & $(0.3)$ & $(0.3)$ & $(0.3)$ & $(0.3)$ & $(0.3)$ \\
\hline \multirow[t]{2}{*}{ Age $35-45$} & 0.42 & 0.54 & 0.57 & 0.48 & 0.56 & 0.34 & 0.39 & 0.51 & 0.42 & 0.45 \\
\hline & $(0.5)$ & $(0.5)$ & $(0.5)$ & $(0.5)$ & $(0.5)$ & $(0.5)$ & $(0.5)$ & $(0.5)$ & $(0.5)$ & $(0.5)$ \\
\hline \multirow[t]{2}{*}{ Age $45-54$} & 0.26 & 0.19 & 0.15 & 0.25 & 0.20 & 0.34 & 0.30 & 0.27 & 0.32 & 0.32 \\
\hline & $(0.4)$ & $(0.4)$ & $(0.4)$ & $(0.4)$ & $(0.4)$ & $(0.5)$ & $(0.5)$ & $(0.4)$ & $(0.5)$ & $(0.5)$ \\
\hline \multirow[t]{2}{*}{ Age $55-64$} & 0.04 & 0.02 & 0.00 & 0.01 & 0.01 & 0.03 & 0.08 & 0.04 & 0.05 & 0.05 \\
\hline & $(0.2)$ & $(0.1)$ & $(0.0)$ & $(0.1)$ & $(0.1)$ & $(0.2)$ & $(0.3)$ & $(0.2)$ & $(0.2)$ & $(0.2)$ \\
\hline \multirow[t]{2}{*}{ Married } & 0.85 & 0.76 & 0.66 & 0.73 & 0.59 & 0.78 & 0.86 & 0.90 & 0.87 & 0.84 \\
\hline & $(0.4)$ & $(0.4)$ & $(0.5)$ & $(0.4)$ & $(0.5)$ & $(0.4)$ & $(0.3)$ & $(0.3)$ & $(0.3)$ & $(0.4)$ \\
\hline \multirow[t]{2}{*}{ Number of children } & 1.86 & 1.79 & 1.73 & 1.81 & 1.68 & 2.00 & 1.87 & 1.62 & 1.81 & 1.66 \\
\hline & (1.0) & $(0.8)$ & $(0.7)$ & $(0.8)$ & $(0.7)$ & (1.1) & $(0.8)$ & $(0.7)$ & $(0.8)$ & $(0.7)$ \\
\hline N. obs & 2251 & 1307 & 165 & 2092 & 447 & 2104 & 775 & 116 & 1595 & 241 \\
\hline
\end{tabular}

Notes: This table shows means and standard deviations of controls used in the analysis by survey year. The samples include all mothers (all fathers) 18-64 who are not students or retired, where mother is defined as having a child under the age of 18 in the house. Sample weighting used.

Source:MTUS (1974-2005) 
TABLE A.5

Total Enrolment and Proportion of Enrolment in Different Groups of Institutions. UK (1974-2005)

\begin{tabular}{|c|c|c|c|c|c|c|}
\hline \multirow{3}{*}{ Year } & \multirow{3}{*}{$\begin{array}{c}\text { All Universities } \\
(1) \\
\text { Enrolment }\end{array}$} & \multirow{3}{*}{$\begin{array}{c}\text { Elite and Non-elite } \\
\text { Universities } \\
(2) \\
\text { Enrolment }\end{array}$} & \multicolumn{2}{|c|}{ Oxbridge } & \multicolumn{2}{|c|}{$\begin{array}{l}\text { Ancient and Civic } \\
\text { Universities }\end{array}$} \\
\hline & & & (3) & (4) & $(5)$ & (6) \\
\hline & & & Enrolment & $\begin{array}{c}\text { Proportion } \\
\text { Out of pre-92 }\end{array}$ & Enrolment & $\begin{array}{c}\text { Proportion } \\
\text { Out of pre-92 }\end{array}$ \\
\hline 1974 & 214,746 & 214,746 & 17,661 & 0.082 & 80,603 & 0.375 \\
\hline 1975 & 224,166 & 224,166 & 17,933 & 0.080 & 82,742 & 0.369 \\
\hline 1976 & 234,773 & 234,773 & 18,427 & 0.078 & 85,462 & 0.364 \\
\hline 1977 & 245,798 & 245,798 & 18,767 & 0.076 & 87,584 & 0.356 \\
\hline 1978 & 254,058 & 254,058 & 19,117 & 0.075 & 89,384 & 0.352 \\
\hline 1979 & 261,093 & 261,093 & 19,256 & 0.074 & 91,266 & 0.350 \\
\hline 1980 & 267,566 & 267,566 & 19,362 & 0.072 & 93,281 & 0.349 \\
\hline 1981 & 270,168 & 270,168 & 19,597 & 0.073 & 94,308 & 0.349 \\
\hline 1982 & 268,085 & 268,085 & 19,536 & 0.073 & 93,316 & 0.348 \\
\hline 1983 & 263,053 & 263,053 & 19,391 & 0.074 & 92,803 & 0.353 \\
\hline 1984 & 266,352 & 266,352 & 19,519 & 0.073 & 92,786 & 0.348 \\
\hline 1985 & 267,953 & 267,953 & 19,915 & 0.074 & 93,696 & 0.350 \\
\hline 1986 & 271,848 & 271,848 & 20,192 & 0.074 & 94,656 & 0.348 \\
\hline 1987 & 276,462 & 276,462 & 20,366 & 0.074 & 95,599 & 0.346 \\
\hline 1988 & 286,016 & 286,016 & 20,607 & 0.072 & 98,030 & 0.343 \\
\hline 1989 & 301,870 & 301,870 & 21,005 & 0.070 & 103,073 & 0.341 \\
\hline 1990 & 317,777 & 317,777 & 21,410 & 0.067 & 108,318 & 0.341 \\
\hline 1991 & 341,616 & 341,616 & 21,444 & 0.063 & 114,887 & 0.336 \\
\hline 1992 & 371,638 & 371,638 & 21,543 & 0.058 & 123,487 & 0.332 \\
\hline 1993 & 402,069 & 402,069 & 21,730 & 0.054 & 132,573 & 0.330 \\
\hline 1994 & 943,239 & 426,283 & 21,345 & 0.050 & 134,313 & 0.315 \\
\hline 1995 & 972,493 & 441,601 & 21,725 & 0.049 & 136,130 & 0.308 \\
\hline 1996 & 997,661 & 461,565 & 21,981 & 0.048 & 140,866 & 0.305 \\
\hline 1997 & $1,022,606$ & 475,868 & 22,178 & 0.047 & 144,108 & 0.303 \\
\hline 1998 & $1,032,897$ & 485,911 & 22,451 & 0.046 & 148,146 & 0.305 \\
\hline 1999 & $1,027,450$ & 486,250 & 22,780 & 0.047 & 148,220 & 0.305 \\
\hline 2000 & $1,037,870$ & 490,060 & 22,485 & 0.046 & 149,280 & 0.305 \\
\hline 2001 & $1,069,215$ & 509,345 & 23,325 & 0.046 & 155,550 & 0.305 \\
\hline 2002 & $1,111,305$ & 532,385 & 23,410 & 0.044 & 162,440 & 0.305 \\
\hline 2003 & $1,141,840$ & 549,350 & 23,400 & 0.043 & 166,760 & 0.304 \\
\hline 2004 & $1,165,465$ & 564,755 & 23,455 & 0.042 & 174,425 & 0.309 \\
\hline 2005 & $1,198,810$ & 575,090 & 24,055 & 0.042 & 175,925 & 0.306 \\
\hline $1974-2005$ & $18,327,958$ & $11,605,570$ & 669,368 & 0.058 & $3,784,017$ & 0.326 \\
\hline
\end{tabular}

Notes: Elite and Non-elite universities exclude those polytechnics granted university status by the 1992 Further and Higher Education Act and any university founded afterwards. Oxbridge includes Oxford and Cambridge Universities. Ancient and Civic Universities are Oxford, Cambridge, St. Andrews, Glasgow, Aberdeen, and Edinburgh, all founded in the Middle Ages, and Birmingham, Liverpool, Manchester, Leeds, Sheffield, and Bristol, founded in the major industrial cities of England before World War I. Columns 4, and 6 calculate the proportion of students attending the group of universities indicated over the total number of students attending pre-92 institutions.

Source: University Statistical Records Microdata (1972-1993) and Higher Education Statistical Agency (1994-2005) 
TABLE A.6

Average Scores and Relative Scores in Different Groups of Institutions UK (1974-1993, 1996-1999)

\begin{tabular}{|c|c|c|c|c|c|}
\hline \multirow{4}{*}{ Year } & \multirow{4}{*}{$\begin{array}{c}\text { Elite and Non-elite Universities } \\
(1) \\
\text { Average } \\
\text { Scores }\end{array}$} & \multicolumn{2}{|c|}{ Oxbridge } & \multicolumn{2}{|c|}{ Ancient and Civic Universties } \\
\hline & & (2) & (3) & (4) & (5) \\
\hline & & Average & Relative & Average & Relative \\
\hline & & Scores & Scores & Scores & Scores \\
\hline 1974 & 16.58 & 24.00 & 1.448 & 17.73 & 1.069 \\
\hline 1975 & 16.55 & 24.00 & 1.450 & 17.74 & 1.072 \\
\hline 1976 & 16.56 & 24.17 & 1.459 & 18.02 & 1.088 \\
\hline 1977 & 16.67 & 24.46 & 1.468 & 18.43 & 1.106 \\
\hline 1978 & 16.70 & 24.60 & 1.473 & 18.56 & 1.111 \\
\hline 1979 & 16.82 & 24.82 & 1.476 & 18.71 & 1.112 \\
\hline 1980 & 17.01 & 25.03 & 1.471 & 18.92 & 1.112 \\
\hline 1981 & 17.36 & 25.29 & 1.457 & 19.28 & 1.110 \\
\hline 1982 & 17.66 & 25.31 & 1.433 & 19.32 & 1.094 \\
\hline 1983 & 18.12 & 25.14 & 1.387 & 19.56 & 1.079 \\
\hline 1984 & 17.90 & 25.18 & 1.407 & 19.79 & 1.106 \\
\hline 1985 & 18.13 & 25.35 & 1.398 & 19.94 & 1.100 \\
\hline 1986 & 18.10 & 25.50 & 1.409 & 19.91 & 1.100 \\
\hline 1987 & 17.93 & 25.64 & 1.430 & 19.72 & 1.100 \\
\hline 1988 & 17.53 & 25.78 & 1.471 & 19.42 & 1.108 \\
\hline 1989 & 17.23 & 25.97 & 1.508 & 19.26 & 1.118 \\
\hline 1990 & 17.17 & 26.01 & 1.515 & 19.15 & 1.115 \\
\hline 1991 & 17.11 & 26.24 & 1.534 & 19.18 & 1.121 \\
\hline 1992 & 16.58 & 26.26 & 1.584 & 18.64 & 1.124 \\
\hline 1993 & 16.17 & 26.25 & 1.623 & 18.25 & 1.129 \\
\hline 1996 & 19.29 & 27.14 & 1.407 & 22.45 & 1.164 \\
\hline 1997 & 20.13 & 27.44 & 1.363 & 23.01 & 1.143 \\
\hline 1998 & 20.36 & 27.49 & 1.350 & 23.21 & 1.140 \\
\hline 1999 & 20.29 & 27.59 & 1.360 & 22.77 & 1.122 \\
\hline 1974-1993/1996-1999 & 17.19 & 25.25 & 1.469 & 18.98 & 1.104 \\
\hline
\end{tabular}

Notes: Oxbridge includes Oxford and Cambridge Universities. Ancient and Civic Universities are Oxford, Cambridge, St. Andrews, Glasgow, Aberdeen, and Edinburgh, all founded in the Middle Ages, and Birmingham, Liverpool, Manchester, Leeds, Sheffield, and Bristol, founded in the major industrial cities of England before World War I. Columns 3, and 5 show the ratio of average scores of students enrolled at elite universities to average scores of all students. The sample includes students with A-level scores as entry qualifications. Individual students' scores are calculated summing up scores from their 3 top A-level scores with A's gaining 10 points, B's, 8, C's, 6, D's, 4, and E's, 2 in USR and two points more, from 12 to 4, in THES.

Source: University Statistical Records Microdata (1972-1993) and Times Higher Education Supplement (1996-1999). 
TABLE A.7

Proportion of Enrolment at Elite Universities by Region. UK (1974-2005)

\begin{tabular}{|c|c|c|c|c|c|c|c|}
\hline Year & North of England & Midlands & East of England & London and South East & South West of England & Wales & Scotland \\
\hline 1974 & 0.607 & 0.552 & 0.660 & 0.500 & 0.357 & 0.000 & 0.463 \\
\hline 1975 & 0.601 & 0.548 & 0.640 & 0.494 & 0.349 & 0.000 & 0.462 \\
\hline 1976 & 0.592 & 0.550 & 0.634 & 0.493 & 0.346 & 0.000 & 0.457 \\
\hline 1977 & 0.587 & 0.530 & 0.619 & 0.489 & 0.342 & 0.000 & 0.458 \\
\hline 1978 & 0.584 & 0.529 & 0.614 & 0.491 & 0.329 & 0.000 & 0.451 \\
\hline 1979 & 0.581 & 0.533 & 0.605 & 0.498 & 0.338 & 0.000 & 0.447 \\
\hline 1980 & 0.583 & 0.533 & 0.601 & 0.500 & 0.337 & 0.000 & 0.450 \\
\hline 1981 & 0.585 & 0.543 & 0.599 & 0.505 & 0.340 & 0.000 & 0.449 \\
\hline 1982 & 0.583 & 0.551 & 0.606 & 0.506 & 0.342 & 0.000 & 0.445 \\
\hline 1983 & 0.594 & 0.564 & 0.612 & 0.502 & 0.344 & 0.000 & 0.453 \\
\hline 1984 & 0.605 & 0.574 & 0.623 & 0.495 & 0.345 & 0.000 & 0.441 \\
\hline 1985 & 0.605 & 0.573 & 0.627 & 0.491 & 0.345 & 0.000 & 0.443 \\
\hline 1986 & 0.598 & 0.576 & 0.629 & 0.489 & 0.344 & 0.000 & 0.441 \\
\hline 1987 & 0.592 & 0.577 & 0.622 & 0.494 & 0.344 & 0.000 & 0.438 \\
\hline 1988 & 0.593 & 0.577 & 0.621 & 0.478 & 0.338 & 0.000 & 0.437 \\
\hline 1989 & 0.592 & 0.573 & 0.611 & 0.469 & 0.328 & 0.000 & 0.434 \\
\hline 1990 & 0.591 & 0.568 & 0.607 & 0.458 & 0.337 & 0.000 & 0.442 \\
\hline 1991 & 0.593 & 0.558 & 0.589 & 0.450 & 0.339 & 0.000 & 0.443 \\
\hline 1992 & 0.586 & 0.551 & 0.568 & 0.440 & 0.331 & 0.000 & 0.449 \\
\hline 1993 & 0.582 & 0.553 & 0.544 & 0.432 & 0.321 & 0.000 & 0.451 \\
\hline 1994 & 0.597 & 0.554 & 0.521 & 0.349 & 0.318 & 0.000 & 0.405 \\
\hline 1995 & 0.597 & 0.578 & 0.507 & 0.331 & 0.316 & 0.000 & 0.416 \\
\hline 1996 & 0.570 & 0.579 & 0.510 & 0.336 & 0.318 & 0.000 & 0.402 \\
\hline 1997 & 0.571 & 0.574 & 0.498 & 0.353 & 0.323 & 0.000 & 0.403 \\
\hline 1998 & 0.572 & 0.568 & 0.506 & 0.366 & 0.325 & 0.000 & 0.416 \\
\hline 1999 & 0.568 & 0.582 & 0.503 & 0.375 & 0.314 & 0.000 & 0.414 \\
\hline 2000 & 0.568 & 0.594 & 0.503 & 0.370 & 0.323 & 0.000 & 0.404 \\
\hline 2001 & 0.572 & 0.601 & 0.500 & 0.370 & 0.320 & 0.000 & 0.397 \\
\hline 2002 & 0.577 & 0.607 & 0.491 & 0.366 & 0.317 & 0.000 & 0.393 \\
\hline 2003 & 0.580 & 0.602 & 0.472 & 0.362 & 0.316 & 0.000 & 0.397 \\
\hline 2004 & 0.615 & 0.606 & 0.456 & 0.359 & 0.317 & 0.000 & 0.397 \\
\hline 2005 & 0.613 & 0.603 & 0.457 & 0.355 & 0.317 & 0.000 & 0.398 \\
\hline
\end{tabular}

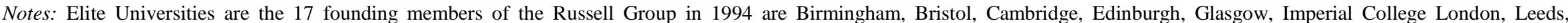
Liverpool, London School of Economics, Manchester, Newcastle, Nottingham, Oxford, Sheffield, Southampton, University College London, and Warwick.

Source: University Statistical Records Microdata (1972-1993) and Higher Education Statistical Agency (1994-2005) 
TABLE A.8

Relative Scores at Elite Institutions by Region. UK (1974-1993, 1996-1999)

\begin{tabular}{|c|c|c|c|c|c|c|c|}
\hline Year & North of England & Midlands & East of Enland & London and South East & South West of England & Wales & Scotland \\
\hline 1972 & 1.041 & 1.126 & 1.129 & 1.121 & 1.142 & 1.000 & 1.092 \\
\hline 1973 & 1.038 & 1.118 & 1.136 & 1.116 & 1.140 & 1.000 & 1.162 \\
\hline 1974 & 1.043 & 1.118 & 1.156 & 1.121 & 1.136 & 1.000 & 1.173 \\
\hline 1975 & 1.049 & 1.116 & 1.181 & 1.129 & 1.146 & 1.000 & 1.102 \\
\hline 1976 & 1.055 & 1.107 & 1.198 & 1.141 & 1.148 & 1.000 & 1.073 \\
\hline 1977 & 1.058 & 1.116 & 1.218 & 1.149 & 1.150 & 1.000 & 1.019 \\
\hline 1978 & 1.057 & 1.113 & 1.224 & 1.150 & 1.186 & 1.000 & 1.012 \\
\hline 1979 & 1.055 & 1.098 & 1.230 & 1.150 & 1.164 & 1.000 & 1.034 \\
\hline 1980 & 1.052 & 1.092 & 1.223 & 1.150 & 1.150 & 1.000 & 1.074 \\
\hline 1981 & 1.050 & 1.081 & 1.225 & 1.141 & 1.133 & 1.000 & 1.094 \\
\hline 1982 & 1.041 & 1.073 & 1.203 & 1.131 & 1.120 & 1.000 & 1.070 \\
\hline 1983 & 1.033 & 1.057 & 1.177 & 1.130 & 1.102 & 1.000 & 1.084 \\
\hline 1984 & 1.030 & 1.042 & 1.161 & 1.126 & 1.098 & 1.000 & 1.093 \\
\hline 1985 & 1.029 & 1.036 & 1.154 & 1.121 & 1.089 & 1.000 & 1.055 \\
\hline 1986 & 1.032 & 1.031 & 1.156 & 1.113 & 1.067 & 1.000 & 1.098 \\
\hline 1987 & 1.035 & 1.026 & 1.165 & 1.114 & 1.073 & 1.000 & 1.110 \\
\hline 1988 & 1.035 & 1.027 & 1.169 & 1.165 & 1.088 & 1.000 & 1.121 \\
\hline 1989 & 1.042 & 1.027 & 1.187 & 1.175 & 1.162 & 1.000 & 1.157 \\
\hline 1990 & 1.049 & 1.034 & 1.195 & 1.186 & 1.167 & 1.000 & 1.116 \\
\hline 1991 & 1.050 & 1.037 & 1.216 & 1.190 & 1.161 & 1.000 & 1.119 \\
\hline 1992 & 1.060 & 1.044 & 1.239 & 1.206 & 1.165 & 1.000 & 1.167 \\
\hline 1993 & 1.062 & 1.042 & 1.270 & 1.220 & 1.188 & 1.000 & 1.184 \\
\hline 1996 & 1.077 & 1.084 & 1.222 & 1.263 & 1.128 & 1.000 & 1.178 \\
\hline 1997 & 1.074 & 1.090 & 1.214 & 1.231 & 1.120 & 1.000 & 1.123 \\
\hline 1998 & 1.078 & 1.083 & 1.210 & 1.204 & 1.118 & 1.000 & 1.138 \\
\hline 1999 & 1.068 & 1.059 & 1.221 & 1.240 & 1.107 & 1.000 & 1.155 \\
\hline
\end{tabular}

Notes: Elite Universities are the 17 founding members of the Russell Group in 1994 are Birmingham, Bristol, Cambridge, Edinburgh, Glasgow, Imperial College London, Leeds, Liverpool, London School of Economics, Manchester, Newcastle, Nottingham, Oxford, Sheffield, Southampton, University College London, and Warwick. The sample includes students with A-level scores as entry qualifications. Individual students' scores are calculated summing up scores from their 3 top A-level scores with A's gaining 10 points, B's, 8, C's, 6, D's, 4, and E's, 2 in USR and two points more, from 12 to 4, in THES.

Source: University Statistical Records Microdata (1972-1993) and Times Higher Education Supplement (1996-1999). 
TABLE A.9

Trends in Parental Time Investments by Educational Attainment and Region. UK (1974, 1983, 2000)

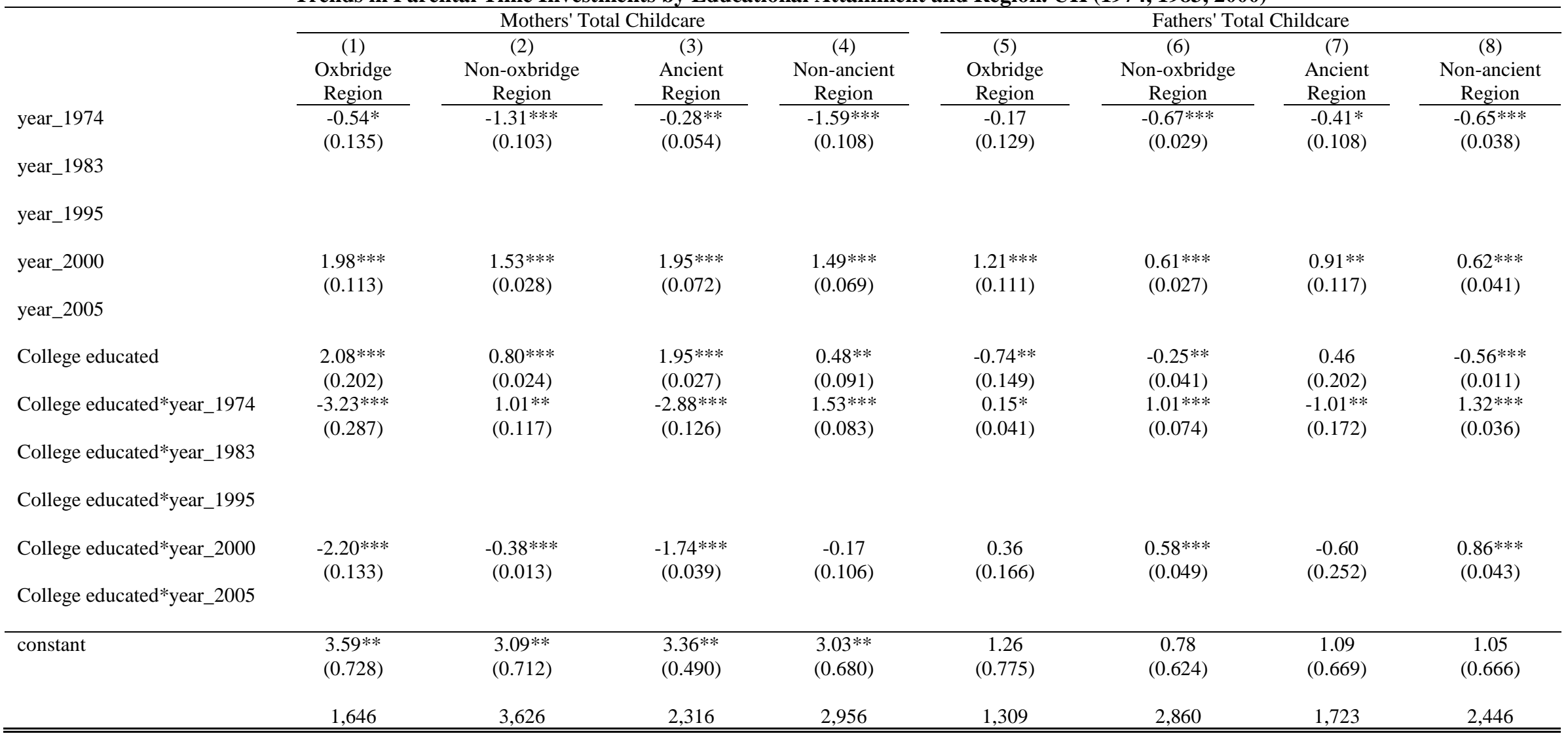

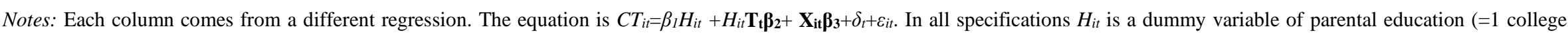

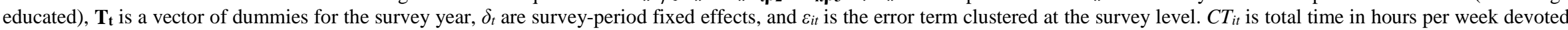

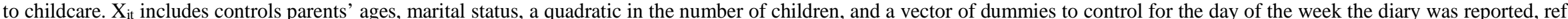

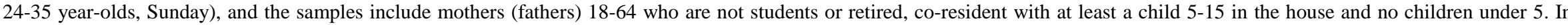

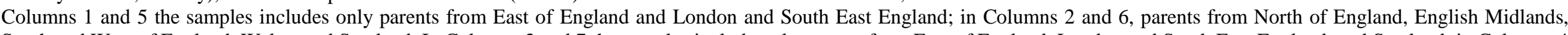

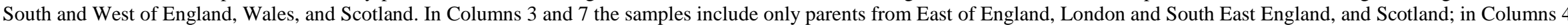
and 8, parents from North of England English Midlands, South and West of England, and Wales. The omitted year is labelled ref. in each column.

Source:MTUS (1974, 1983, 2000)

*** Significant at the 1 percent level. ** Significant at the 5 percent level. 
TABLE A.10

Trends in Parental Time Investments by Educational Attainment and Region Controlling for Income. UK (1974, 1983, 1995, 2000, 2005)

\begin{tabular}{|c|c|c|c|c|c|c|c|c|}
\hline & \multicolumn{4}{|c|}{ Mothers } & \multicolumn{4}{|c|}{ Fathers } \\
\hline & (1) & $(2)$ & $(3)$ & (4) & (5) & $(6)$ & $(7)$ & $(8)$ \\
\hline & Oxbridge & Non-oxbridge & Civic & Non-civic & Oxbridge & Non-oxbridge & Civic & Non-civic \\
\hline & Regions & Regions & Regions & Regions & Regions & Regions & Regions & Regions \\
\hline \multirow[t]{2}{*}{ year_1974 } & $-0.52 * *$ & $-1.30 * * *$ & $-0.17 * *$ & $-1.59 * * *$ & -0.16 & $-0.65 * * *$ & -0.28 & $-0.65 * * *$ \\
\hline & $(0.133)$ & $(0.094)$ & $(0.046)$ & $(0.093)$ & $(0.183)$ & $(0.023)$ & $(0.203)$ & $(0.019)$ \\
\hline \multicolumn{9}{|l|}{ year_1983 } \\
\hline \multirow[t]{2}{*}{ year_1995 } & $3.91 * * *$ & $4.55 * * *$ & $3.79 * * *$ & $4.65 * * *$ & $-0.53 * *$ & $3.48 * * *$ & $-0.29 * *$ & $3.93 * * *$ \\
\hline & $(0.066)$ & $(0.107)$ & $(0.049)$ & $(0.163)$ & $(0.134)$ & $(0.186)$ & $(0.101)$ & $(0.199)$ \\
\hline \multirow[t]{2}{*}{ year_2000 } & $1.93 * * *$ & $1.52 * * *$ & $1.98 * * *$ & $1.48 * * *$ & $1.16^{* * *}$ & $0.54 * * *$ & $0.96^{* * *}$ & $0.53 * * *$ \\
\hline & $(0.110)$ & $(0.055)$ & $(0.057)$ & $(0.089)$ & $(0.140)$ & $(0.071)$ & $(0.110)$ & $(0.087)$ \\
\hline \multirow[t]{2}{*}{ year_2005 } & $4.91 * * *$ & $4.54 * * *$ & $6.04 * * *$ & $3.87 * * *$ & $5.47 * * *$ & $2.42 * * *$ & $5.01 * * *$ & $2.24 * * *$ \\
\hline & $(0.146)$ & $(0.129)$ & $(0.111)$ & $(0.203)$ & $(0.172)$ & $(0.093)$ & $(0.093)$ & $(0.121)$ \\
\hline \multirow[t]{2}{*}{ College educated } & $1.87 * * *$ & $0.52 * * *$ & $1.86 * * *$ & 0.03 & $-0.76 * * *$ & $-0.41 * *$ & 0.42 & $-0.72 * *$ \\
\hline & $(0.184)$ & $(0.074)$ & $(0.054)$ & $(0.097)$ & $(0.136)$ & $(0.131)$ & $(0.253)$ & $(0.213)$ \\
\hline \multirow[t]{2}{*}{ College educated*year_1974 } & $-3.46 * * *$ & $1.13 * * *$ & $-3.14 * * *$ & $1.71 * * *$ & 0.27 & $0.87 * * *$ & $-0.97 * *$ & $1.27 * * *$ \\
\hline & $(0.292)$ & $(0.146)$ & $(0.170)$ & $(0.208)$ & $(0.162)$ & $(0.152)$ & $(0.281)$ & $(0.080)$ \\
\hline \multicolumn{9}{|l|}{ College educated*year_1983 } \\
\hline \multirow[t]{2}{*}{ College educated*year_1995 } & $8.09 * * *$ & -0.27 & $5.66 * * *$ & -0.84 & $7.02 * * *$ & $-1.71 * * *$ & $3.83^{* * *}$ & $-1.06 * *$ \\
\hline & $(0.443)$ & $(0.251)$ & $(0.328)$ & $(0.462)$ & $(0.361)$ & $(0.253)$ & $(0.286)$ & $(0.290)$ \\
\hline \multirow[t]{2}{*}{ College educated*year_2000 } & $-2.14 * * *$ & -0.09 & $-1.83 * * *$ & $0.28^{*}$ & $0.42 * *$ & $0.61 * * *$ & $-0.59 *$ & $0.94 * * *$ \\
\hline & $(0.127)$ & $(0.082)$ & $(0.069)$ & $(0.126)$ & $(0.110)$ & $(0.103)$ & $(0.248)$ & $(0.135)$ \\
\hline \multirow[t]{2}{*}{ College educated*year_2005 } & $-2.23 * * *$ & $-0.60 * * *$ & $-2.76 * * *$ & 0.10 & $-2.15 * * *$ & $0.81 * * *$ & $-1.93 * * *$ & $0.34 *$ \\
\hline & $(0.254)$ & $(0.078)$ & $(0.130)$ & $(0.076)$ & $(0.094)$ & $(0.091)$ & $(0.180)$ & $(0.139)$ \\
\hline \multirow[t]{3}{*}{ constant } & $2.94 * *$ & $1.92 *$ & $3.09 * * *$ & 1.66 & 2.23 & 1.73 & 1.53 & 2.17 \\
\hline & (0.778) & $(0.818)$ & $(0.326)$ & (1.103) & (1.630) & (1.388) & (1.131) & (1.470) \\
\hline & 1,832 & 4,052 & 2,551 & 3,333 & 1,437 & 3,089 & 1,878 & 2,648 \\
\hline
\end{tabular}

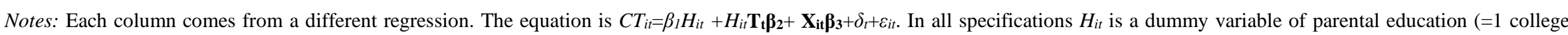

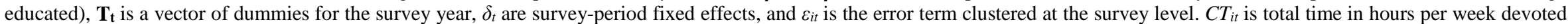

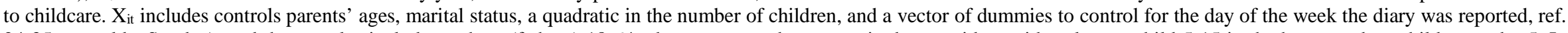

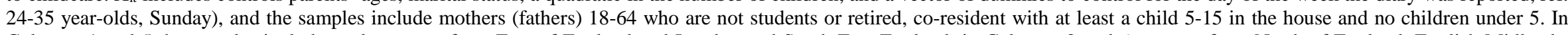

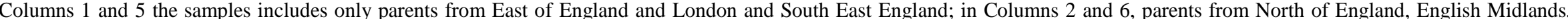

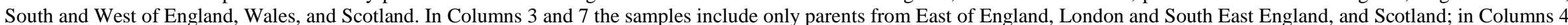
and 8, parents from North of England English Midlands, South and West of England, and Wales. The omitted year is labelled ref. in each column.

Source:MTUS (1974, 1983, 1995, 2000, 2005)

*** Significant at the 1 percent level. ** Significant at the 5 percent level. 
TABLE A.11

Descriptive Statistics of ICVS Sample. UK (1989, 1996, 2000, 2005)

\begin{tabular}{|c|c|c|c|c|c|c|c|c|}
\hline & \multicolumn{4}{|c|}{ Women } & \multicolumn{4}{|c|}{ Men } \\
\hline & 1989 & 1996 & 2000 & 2005 & 1989 & 1996 & 2000 & 2005 \\
\hline \multirow[t]{2}{*}{ Feelings of unsafety } & & 0.12 & 0.10 & 0.12 & & 0.04 & 0.02 & 0.06 \\
\hline & & $(0.3)$ & $(0.3)$ & $(0.3)$ & & $(0.2)$ & $(0.1)$ & $(0.2)$ \\
\hline \multirow[t]{2}{*}{ Likelihood of burglary } & 0.08 & 0.13 & 0.06 & 0.09 & 0.08 & 0.08 & 0.05 & 0.05 \\
\hline & $(0.3)$ & $(0.3)$ & $(0.2)$ & $(0.3)$ & $(0.3)$ & $(0.3)$ & $(0.2)$ & $(0.2)$ \\
\hline \multirow[t]{2}{*}{ Some college or more } & 0.28 & 0.22 & 0.27 & 0.42 & 0.42 & 0.28 & 0.38 & 0.42 \\
\hline & $(0.4)$ & $(0.4)$ & $(0.4)$ & $(0.5)$ & $(0.5)$ & $(0.4)$ & $(0.5)$ & $(0.5)$ \\
\hline \multirow[t]{2}{*}{ Age 18-24 } & 0.16 & 0.09 & 0.13 & 0.08 & 0.16 & 0.10 & 0.13 & 0.10 \\
\hline & $(0.4)$ & $(0.3)$ & $(0.3)$ & $(0.3)$ & $(0.4)$ & $(0.3)$ & $(0.3)$ & $(0.3)$ \\
\hline \multirow[t]{2}{*}{ Age $25-34$} & 0.15 & 0.19 & 0.15 & 0.13 & 0.12 & 0.16 & 0.19 & 0.12 \\
\hline & $(0.4)$ & $(0.4)$ & $(0.4)$ & $(0.3)$ & $(0.3)$ & $(0.4)$ & $(0.4)$ & $(0.3)$ \\
\hline \multirow[t]{2}{*}{ Age $35-45$} & 0.25 & 0.28 & 0.25 & 0.32 & 0.23 & 0.27 & 0.25 & 0.28 \\
\hline & $(0.4)$ & $(0.4)$ & $(0.4)$ & $(0.5)$ & $(0.4)$ & $(0.4)$ & $(0.4)$ & $(0.4)$ \\
\hline \multirow[t]{2}{*}{ Age $45-54$} & 0.15 & 0.21 & 0.23 & 0.19 & 0.16 & 0.22 & 0.21 & 0.21 \\
\hline & $(0.4)$ & $(0.4)$ & $(0.4)$ & $(0.4)$ & $(0.4)$ & $(0.4)$ & $(0.4)$ & $(0.4)$ \\
\hline \multirow[t]{2}{*}{ Age $55-64$} & 0.16 & 0.11 & 0.11 & 0.15 & 0.20 & 0.12 & 0.12 & 0.17 \\
\hline & $(0.4)$ & $(0.3)$ & $(0.3)$ & $(0.4)$ & $(0.4)$ & $(0.3)$ & $(0.3)$ & $(0.4)$ \\
\hline \multirow[t]{2}{*}{ Children in the household } & 0.48 & 0.54 & 0.02 & 0.00 & 0.41 & 0.43 & 0.02 & 0.00 \\
\hline & $(0.5)$ & $(0.5)$ & $(0.1)$ & $(0.0)$ & $(0.5)$ & $(0.5)$ & $(0.1)$ & $(0.0)$ \\
\hline N. obs & 2631 & 1997 & 2082 & 759 & 2264 & 1790 & 1715 & 562 \\
\hline
\end{tabular}

Notes: This table shows means and standard deviations of dependent variables and controls used in the analysis by survey year. The samples include all women (all men) 18-64 who are not students or retired. Sample weighting used.

Source: International Crime Victims Survey Data, 1989-2005. 
TABLE A. 12

Descriptive Statistics of WVS and EVS Sample. UK $(1981,1990,1999,2005)$

\begin{tabular}{|c|c|c|c|c|c|c|c|c|}
\hline & \multicolumn{4}{|c|}{ Mothers } & \multicolumn{4}{|c|}{ Fathers } \\
\hline & 1989 & 1996 & 2000 & 2005 & 1989 & 1996 & 2000 & 2005 \\
\hline \multirow[t]{2}{*}{ Independence } & 0.28 & 0.54 & 0.61 & 0.65 & 0.22 & 0.34 & 0.61 & 0.58 \\
\hline & $(0.4)$ & $(0.5)$ & $(0.5)$ & $(0.5)$ & $(0.4)$ & $(0.5)$ & $(0.5)$ & $(0.5)$ \\
\hline \multirow[t]{2}{*}{ Hard work } & 0.13 & 0.22 & 0.30 & 0.37 & 0.16 & 0.31 & 0.46 & 0.51 \\
\hline & $(0.3)$ & $(0.4)$ & $(0.5)$ & $(0.5)$ & $(0.4)$ & $(0.5)$ & $(0.5)$ & $(0.5)$ \\
\hline \multirow[t]{2}{*}{ Feeling of responsibility } & 0.31 & 0.49 & 0.62 & 0.61 & 0.23 & 0.47 & 0.51 & 0.57 \\
\hline & $(0.5)$ & $(0.5)$ & $(0.5)$ & $(0.5)$ & $(0.4)$ & $(0.5)$ & $(0.5)$ & $(0.5)$ \\
\hline \multirow[t]{2}{*}{ Tolerance } & 0.11 & 0.23 & 0.38 & 0.42 & 0.16 & 0.24 & 0.45 & 0.43 \\
\hline & $(0.3)$ & $(0.4)$ & $(0.5)$ & $(0.5)$ & $(0.4)$ & $(0.4)$ & $(0.5)$ & $(0.5)$ \\
\hline \multirow[t]{2}{*}{ Frugality } & 0.71 & 0.80 & 0.89 & 0.87 & 0.54 & 0.80 & 0.76 & 0.85 \\
\hline & $(0.5)$ & $(0.4)$ & $(0.3)$ & $(0.3)$ & $(0.5)$ & $(0.4)$ & $(0.4)$ & $(0.4)$ \\
\hline \multirow[t]{2}{*}{ Perseverance } & 0.08 & 0.26 & 0.28 & 0.20 & 0.08 & 0.24 & 0.31 & 0.25 \\
\hline & $(0.3)$ & $(0.4)$ & $(0.5)$ & $(0.4)$ & $(0.3)$ & $(0.4)$ & $(0.5)$ & $(0.4)$ \\
\hline \multirow[t]{2}{*}{ Religious faith } & 0.10 & 0.16 & 0.12 & 0.18 & 0.08 & 0.13 & 0.14 & 0.17 \\
\hline & $(0.3)$ & $(0.4)$ & $(0.3)$ & $(0.4)$ & $(0.3)$ & $(0.3)$ & $(0.3)$ & $(0.4)$ \\
\hline \multirow[t]{2}{*}{ Obedience } & 0.31 & 0.40 & 0.53 & 0.47 & 0.39 & 0.36 & 0.54 & 0.38 \\
\hline & $(0.5)$ & $(0.5)$ & $(0.5)$ & $(0.5)$ & $(0.5)$ & $(0.5)$ & $(0.5)$ & $(0.5)$ \\
\hline \multirow[t]{2}{*}{ Some college or more } & 0.08 & 0.15 & 0.18 & 0.26 & 0.09 & 0.18 & 0.26 & 0.31 \\
\hline & $(0.3)$ & $(0.4)$ & $(0.4)$ & $(0.4)$ & $(0.3)$ & $(0.4)$ & $(0.4)$ & $(0.5)$ \\
\hline \multirow[t]{2}{*}{ Age 18-24 } & 0.17 & 0.06 & 0.10 & 0.05 & 0.19 & 0.05 & 0.11 & 0.02 \\
\hline & $(0.4)$ & $(0.2)$ & $(0.3)$ & $(0.2)$ & $(0.4)$ & $(0.2)$ & $(0.3)$ & $(0.2)$ \\
\hline \multirow[t]{2}{*}{ Age $25-34$} & 0.33 & 0.33 & 0.36 & 0.20 & 0.27 & 0.23 & 0.32 & 0.18 \\
\hline & $(0.5)$ & $(0.5)$ & $(0.5)$ & $(0.4)$ & $(0.4)$ & $(0.4)$ & $(0.5)$ & $(0.4)$ \\
\hline \multirow[t]{2}{*}{ Age $35-45$} & 0.33 & 0.34 & 0.37 & 0.34 & 0.32 & 0.42 & 0.37 & 0.36 \\
\hline & $(0.5)$ & $(0.5)$ & $(0.5)$ & $(0.5)$ & $(0.5)$ & $(0.5)$ & $(0.5)$ & $(0.5)$ \\
\hline \multirow[t]{2}{*}{ Age $45-54$} & 0.13 & 0.23 & 0.17 & 0.24 & 0.17 & 0.22 & 0.14 & 0.23 \\
\hline & $(0.3)$ & $(0.4)$ & $(0.4)$ & $(0.4)$ & $(0.4)$ & $(0.4)$ & $(0.3)$ & $(0.4)$ \\
\hline \multirow[t]{2}{*}{ Age 55-64 } & 0.04 & 0.04 & 0.01 & 0.17 & 0.06 & 0.08 & 0.07 & 0.21 \\
\hline & $(0.2)$ & $(0.2)$ & $(0.1)$ & $(0.4)$ & $(0.2)$ & $(0.3)$ & $(0.3)$ & $(0.4)$ \\
\hline \multirow[t]{2}{*}{ Married } & 0.80 & 0.85 & 0.60 & 0.72 & 0.80 & 0.95 & 0.70 & 0.79 \\
\hline & $(0.4)$ & $(0.4)$ & $(0.5)$ & $(0.5)$ & $(0.4)$ & $(0.2)$ & $(0.5)$ & $(0.4)$ \\
\hline N. obs & 273 & 343 & 274 & 304 & 251 & 244 & 128 & 226 \\
\hline
\end{tabular}

Notes: This table shows means and standard deviations of dependent variables and controls used in the analysis by survey year. The samples include all mothers (all fathers 18-64 who are not students or retired. Sample weighting used.

Source: European Values Study (1981, 1990, and 1999) and World Values Survey Data, 2005. 
TABLE A.13

Parenting Values Index Loading Factors. UK (1981, 1990, 1999, 2005).

\begin{tabular}{lcc}
\hline & $(1)$ & $(2)$ \\
& Mothers & Fathers \\
\hline Independence & 0.479 & 0.749 \\
Hard work & 0.303 & 0.255 \\
Feeling of responsibility & 0.285 & 0.454 \\
Imagination & 0.343 & 0.512 \\
Tolerance & -0.072 & 0.023 \\
Frugality & 0.181 & 0.043 \\
Religious faith & -0.246 & -0.260 \\
Obedience & -0.364 & -0.549 \\
\hline Proportion of variance & 17.17 & 18.73 \\
\hline \hline
\end{tabular}

Notes: This table shows the weights assigned to each variable for the first principal component in constructing mothers' and fathers' composite measures of parenting values. The three highest factor loadings are shaded in grey. The last row also shows the proportion of variance attributable to the first principal component.

Source: European Values Study $(1981,1990,1999)$ and World Values Survey $(2005)$. 


\section{Appendix B. Data Appendix}

\section{B.1 College competition data}

To calculate our competition measures, we construct time series for student numbers and average Alevel scores by institution from 1974 to 2005 using data from three different sources: the Universities' Statistical Record (USR), the Higher Education Statistics Agency (HESA), and the Times Higher Education Supplement (THES). Region of origin was also manually added for each institution by the authors according to the location of the university.

Time series for student numbers come from USR and HESA data. URS offers individual student records for the full population of undergraduate students from 1974/75 to 1993/94 and includes information on institution, admission grades, nationality, and type of studies, among others. The HESA on-line publication Students in Higher Education provides information on the number of students by institution, mode of study, level of study, and domicile in its tables 0a from 1995/96 onwards. For the year 1994/95 HESA offers just the total number of full-time undergraduates by institution and so this is the definition of student numbers used in the computation of enrolment rates. Comparability in student numbers across both datasets is assured by selecting full-time undergraduate students from USR, as defined by HESA (UK and foreign full-time students, plus students in sandwich years and spending an obligatory year away from the university, e.g., language students abroad). Therefore we first count the total number of full-time undergraduate students by institution and cohort from the individual files in USR. We then manually add total full-time undergraduate students by institution for the year 1994/1995 from Students in Higher Education Institutions 1994/95. And finally we include total fulltime undergraduate students for 1995/96 to 2004/05 from HESA web site.

Times series for average entry qualifications by institution come from USR and THES data. USR offers student-level information on Advanced (A)-level and Scottish qualifications from 1974/75 to 1993/94. Available THES data, provided by Andrew Abbot as used in Abbott and Leslie (2004), 
offered just average A-level qualifications for 1996/97 to 1999/2000. We therefore use average Alevels from both datasets, and drop approximately 10 percent of the student observations from USR. USR and THES compute average A-level entry scores by summing up scores from each student's 3 top A-level scores (an A score being 10 points, a B score being 8, a C score being 6, a D score being 4, and a $\mathrm{E}$ score 2 in USR and two points more, from 12 to 4, for A to E, in THES). Average entry qualifications are weighted by UK student numbers in order to compute relative scores. We construct trends in total UK undergraduate students from USR and HESA following a similar method to the one explained for computation of full-time undergraduate students.

\section{B.2 Safety concerns data}

We use data from the International Crime Victims Survey (ICVS) for the years 1989, 1996, 2000, and 2004 (van Kesteren, 1989-2005). We use the question "What would you say are the chances that over the next twelve months someone will try to break into your home?" from the International Crime Victims Survey (ICVS) for the years 1989, 1996, 2000, and 2004 (van Kesteren, 1989-2005), and construct a variable of fears of house burglary by coding responses as a dummy (1, if the answer to the question is very likely; zero, otherwise). We also use "How safe do you feel when walking alone on the street after dark?", and construct a variable of feelings of unsafety on the street by coding responses as a dummy (1, if the answer to the question is "very unsafe", and zero otherwise). We select all individuals aged 18-65 who are not student or retired. Descriptive statistics are provided in Table A.11 in the Appendix A.

\section{B.3 Parenting values data}

We use information from the European Values Study (1981, 1990, and 1999) and World Values Survey Data, 2005 (WVS, 2005-2007) for a sample of parents aged 18-65. In these surveys respondents are presented with a list of qualities that "children can be encouraged to learn at home", and are asked 
to choose up to five qualities that they consider to be particularly important. The qualities are independence, hard work, feeling of responsibility, tolerance and respect, thrift, saving money and things, determination, perseverance, religious faith, and obedience. Descriptive statistics are provided in Table A.12 in the Appendix A. We construct a parenting values index using principal component analysis of all these measures. The principal component analysis puts a high negative weight on obedience and a high positive weight on independence and imagination (see Table A.13 in the Appendix A). We follow the economics literature and interpret lower values in the parenting values index as indicative of a less time-intensive authoritarian parenting, and interpret higher values of the parenting values index to be more in line with the more time-intensive concerted cultivation parenting approach, which places more emphasis in reasoning rather than directing children's behaviour (see Doepke and Zilibotti, 2017). 